\title{
Fusion Proteins for Half-Life Extension of Biologics as a Strategy to Make Biobetters
}

\author{
William R. Strohl ${ }^{1}$
}

Published online: 16 July 2015

(c) The Author(s) 2015. This article is published with open access at Springerlink.com

\begin{abstract}
The purpose of making a "biobetter" biologic is to improve on the salient characteristics of a known biologic for which there is, minimally, clinical proof of concept or, maximally, marketed product data. There already are several examples in which second-generation or biobetter biologics have been generated by improving the pharmacokinetic properties of an innovative drug, including Neulasta ${ }^{\circledR}$ [a PEGylated, longer-half-life version of Neupogen ${ }^{\circledR}$ (filgrastim)] and Aranesp ${ }^{\circledR}$ [a longer-halflife version of Epogen ${ }^{\circledR}$ (epoetin- $\alpha$ )]. This review describes the use of protein fusion technologies such as Fc fusion proteins, fusion to human serum albumin, fusion to carboxy-terminal peptide, and other polypeptide fusion approaches to make biobetter drugs with more desirable pharmacokinetic profiles.
\end{abstract}

William R. Strohl

wstrohl@its.jnj.com

Janssen BioTherapeutics, Janssen Research and Development, LLC, Pharmaceutical Companies of Johnson \& Johnson, SH31-21757, 1400 Welsh and McKean Roads, PO Box 776, Spring House, PA 19477, USA

\section{Key Points}

Biobetters are biologics based on an innovative biologic but with improved properties.

Fusion proteins have been used in the biopharmaceutical industry for over 25 years to improve the pharmacokinetic properties of otherwise short-half-life biologics.

Biobetter fusion proteins with longer half-lives or with targeting moieties are being developed for several innovative biologic drugs.

\section{Introduction to Protein Pharmacokinetics and Elimination}

There are now more than 180 therapeutic proteins and peptides approved by the US Food and Drug Administration (FDA) for a wide variety of indications, ranging from alleviation of neuropathic pain to rheumatoid arthritis and replacement enzymes for lysosomal storage diseases. Many of these proteins and peptides have less than optimal pharmacokinetic properties, often because they are smaller than the kidney filtration cutoff of around $70 \mathrm{kDa}[1,2]$ and/or are subject to metabolic turnover by peptidases, which significantly limits their in vivo half-life [3]. An example of this is the serum half-life of native glucagonlike peptide (GLP)-1, which is about 1-2 min, primarily because of peptidic cleavage by dipeptidyl peptidase (DPP)-4 [4, 5]. Moreover, for virtually all of these proteins and peptides, dosing is parenteral, so each dose is represented by either a subcutaneous or intravenous injection. 
High dosing frequency, a small area under the curve (AUC), and patient inconvenience are limitations of shortacting peptides. Thus, in many cases, second- or thirdgeneration modifications of those protein or peptide drugs, intended to decrease their sensitivity to proteases [5] and glomerular filtration by the kidney $[1,2]$, have been developed to improve their pharmacokinetic profiles.

Pharmacokinetics is often described as what the body does to the drug, whereas pharmacodynamics is described as what the drug does to the body. The pharmacokinetics of proteins and peptides is governed by the parameters of absorption, biodistribution, metabolism, and elimination. Absorption of peptides and proteins is generally via the lymphatic system [6], biodistribution is generally limited to the extracellular space in the central compartment (e.g., $3-8 \mathrm{~L}$ [5]), the volume of distribution is generally $<15 \mathrm{~L}$, metabolism occurs through enzymatic cleavage by proteases and peptidases [3-5], and proteins and peptides are eliminated from the serum by several different tissue- and receptor-mediated mechanisms. The most common routes of clearance for proteins and peptides include endocytosis and membrane transport-mediated clearance by liver hepatocytes for larger proteins, and glomerular filtration by the kidney for smaller proteins and peptides $[1,5]$.

While not all of the parameters involved in glomerular filtration of peptides and proteins are fully understood yet, it is clear that size, shape, hydrodynamic radius, and charge all play significant roles [1,2]. Generally, proteins and peptides smaller than approximately $70 \mathrm{kDa}$ are more likely to be eliminated by kidney filtration than are larger proteins $[1,2]$. Additionally, charge plays a significant role in glomerular filtration. Negatively charged peptides or smaller proteins may be eliminated less readily than neutral polypeptides because of repulsion by the negatively charged basement membrane of the kidney [1,7]. Cationic polypeptides, on the other hand, tend to be removed even more quickly [7]. Thus, two key strategies have been employed to improve the pharmacokinetics of smaller proteins and peptides, i.e., increasing the size and hydrodynamic radius of the protein or peptide, or increasing the negative charge of the target protein or peptide. A third strategy, similar to that employed with small molecules, is to increase the level of serum protein binding of the peptide or protein through binding to albumin [8, 9] or immunoglobulins [10].

Traditionally, the typical modification made in the past to improve the pharmacokinetics of peptide or biologic drugs was via conjugation to either linear or branchedchain monomethoxy poly-ethylene glycol (PEG), resulting in increases in the molecular mass and hydrodynamic radius, and a decrease in the rate of glomerular filtration by the kidney [1, 2, 11, 12]. PEG is a highly flexible, uncharged, mostly non-immunogenic, hydrophilic, non- biodegradable molecule, which generates a larger hydrodynamic radius than an equivalently sized protein $[1,2]$. PEGylation has been used widely as a means to lengthen the half-life of proteins, e.g., PegIntron ${ }^{\circledR}$ [PEGylated interferon (IFN)- $\left.\alpha_{2 b}\right]$ and Pegasys ${ }^{\circledR}$ (PEGylated IFN- $\alpha_{2 a}$ ) for treatment of hepatitis B, Neulasta ${ }^{\circledR}$ (a PEG-conjugated granulocyte colony-stimulating factor $[\mathrm{G}-\mathrm{CSF}]$ for treatment of chemotherapy-induced neutropenia), and Mycera ${ }^{\circledR}$ (a PEGylated form of epoetin- $\beta$ ). While PEG has been approved by the FDA as a GRAS (generally recognized as safe) molecule [13], it has been associated with vacuolization of renal cortical tubular epithelium cells [14], bringing its safety at least somewhat into question. Additionally, PEG is not metabolized by the body. Because of safety concerns - as well as the high cost of PEG itself and the need for chemical conjugation to the protein, followed by repurification of the conjugate [15] - more and more companies are seeking safer and less expensive alternatives to PEGylation. Another approach that has been utilized to improve pharmacokinetic parameters includes modification of glycosylation patterns, resulting in reduced clearance and extension of half-life. The best example of this approach is Aranesp ${ }^{\circledR}$ (darbepoetin- $\alpha$ ), a second-generation epoetin with modified glycosylation, which has a threefold longer half-life than epoetin- $\alpha$ [16]. Table 1 provides a few historical examples in which peptide or protein drugs have been modified by non-fusion protein approaches to improve either pharmacokinetics, biodistribution, or both.

In this review, protein fusion methods for improving the pharmacokinetics of peptides and small proteins are discussed in some detail. The most widely used of these approaches include fusion of the biologically active protein or peptide to human serum albumin (HSA), fusion to the constant fragment $(\mathrm{Fc})$ domain of a human immunoglobulin (Ig) G, or fusion to non-structured polypeptides such as XTEN [17]. The intent here is to demonstrate both examples and possibilities for generating improved biologics, or "biobetters", from proteins or peptides that have desired pharmacological properties but less than optimal pharmacokinetic properties. Of 43 fusion proteins (FPs) recently found in phase 2 or phase 3 clinical trial development, 20 have been identified as being constructed strictly for extension of half-life [18]. Protein fusion biobetters employing targeting approaches are touched upon as well.

\section{Definition of "Biobetter"}

Since the goal of the research described in this review is to make "biobetter" molecules, it is critical to define what a "biobetter" is and to differentiate it from "biosimilar" (which is intended to be a close copy of the originator's 
Table 1 Examples in which non-protein-fusion second-generation versions of an originator protein or peptide have been generated primarily by altering pharmacokinetics

\begin{tabular}{|c|c|c|c|c|}
\hline $\begin{array}{l}\text { Name of } \\
\text { "biobetter" }\end{array}$ & $\begin{array}{l}\text { Approach used for } \\
\text { half-life extension }\end{array}$ & $\begin{array}{l}\text { Company or researcher and } \\
\text { date of approval }\end{array}$ & $\begin{array}{l}\text { Name of } \\
\text { innovative } \\
\text { biologic }\end{array}$ & $\begin{array}{l}\text { Innovator company and } \\
\text { date of original approval }\end{array}$ \\
\hline $\begin{array}{l}\text { Neulasta }{ }^{\circledR} \\
\text { (PEG-filgrastim) }\end{array}$ & PEGylation & Amgen (approved Jan 2002) & $\begin{array}{l}\text { Neupogen }{ }^{\circledR} \\
\quad \text { (filgrastim) }\end{array}$ & Amgen (approved Feb 1991) \\
\hline $\begin{array}{l}\text { Aranesp }^{\circledR} \\
(\text { darbepoetin- } \alpha)\end{array}$ & $\begin{array}{l}\text { Modified } \\
\text { glycosylation }\end{array}$ & Amgen (approved Sep 2001) & $\begin{array}{l}\text { Epogen }^{\circledR} \\
\quad(\text { epoetin- } \alpha)\end{array}$ & Amgen (approved Jun 1989) \\
\hline $\begin{array}{l}\text { Plegridy } \\
\left(\text { PEG-IFN- } \beta_{1 \mathrm{a}}\right)\end{array}$ & PEGylation & Biogen Idec (approved Aug 2014) & $\begin{array}{l}\text { Avonex }{ }^{\circledR} \\
\left(\text { IFN- } \beta_{1 \mathrm{a}}\right)\end{array}$ & Biogen (approved May 1996) \\
\hline $\begin{array}{l}\text { PegIntron }{ }^{\circledR} \\
{\left.\text { (PEG-IFN- } \alpha_{2 b}\right)}\end{array}$ & PEGylation & $\begin{array}{l}\text { Schering (now Merck) (approved Jun } \\
\text { 2001) }\end{array}$ & $\begin{array}{l}\text { Intron } A^{\circledR} \\
\left(\operatorname{IFN}-\alpha_{2 b}\right)\end{array}$ & $\begin{array}{l}\text { Schering [now Merck] (approved } \\
\text { Jun 1986) }\end{array}$ \\
\hline $\begin{array}{l}\text { Pegasys }{ }^{\circledR} \\
\left(\text { PEG-IFN- } \alpha_{2 a}\right)\end{array}$ & PEGylation & $\begin{array}{l}\text { Hoffman-La Roche (originally approved } \\
\text { Sep 2002) }\end{array}$ & $\begin{array}{l}\text { Roferon-A }{ }^{\circledR} \\
\left(\text { IFN- } \alpha_{2 a}\right)\end{array}$ & $\begin{array}{l}\text { Hoffman-La Roche (approved Jun } \\
\text { 1986) }\end{array}$ \\
\hline
\end{tabular}

Raw data were obtained from the US Food and Drug Administration website and assembled

IFN interferon, $P E G$ poly-ethylene glycol

innovative drug [19]) and next-generation molecules (which may have additional characteristics that separate it from the original innovative molecule). The innovative molecule is the first one to be developed and marketed. Examples of innovative molecules pertinent to this discussion are Victoza $^{\circledR}$ (liraglutide; modified, acylated GLP-1), Roferon- ${ }^{\circledR}$ $\left(\right.$ IFN- $\left.\alpha_{2 \mathrm{a}}\right)$, Nutropin $\mathrm{AQ}^{\circledR}$ [somatropin; human growth hormone (hGH)], and Neupogen ${ }^{\circledR}$ [filgrastim; recombinant human G-CSF (rhG-CSF)]. A biobetter form of one of these molecules would involve taking the originator molecule and making specific alterations in it to improve its parameters and thereby make it a more efficacious, less frequently dosed, better targeted, and/or better tolerated drug. Thus, an HSA fusion of hGH, which would give the pharmacologically active hGH a significantly longer serum half-life and reduce dosing frequency, could be a "biobetter" version of hGH. On the other hand, a novel peptide or protein binding to the hGH receptor in a manner not necessarily exactly like the binding of hGH would be classified as a next-generation biologic [19]. An example of a potential next-generation biologic is the monoclonal antibody CG-172, an hGH receptor agonist that demonstrates signaling capabilities somewhat different than those generated by hGH agonism of the hGH receptor [20].

\section{Major Types of Fusion Proteins for Improvement in Pharmacokinetics}

As mentioned above, many peptides and proteins have half-life profiles that are not optimal for parenteral therapeutic dosing. To address this shortcoming, typically one of six general strategies for prolongation of half-life has been, or may be, used (Table 2):
1. Genetic fusion of the pharmacologically active peptide or protein to a naturally long-half-life protein or protein domain (e.g., Fc fusion [21-23], transferrin [Tf] fusion [24], or albumin fusion [25, 26]).

2. Genetic fusion of the pharmacologically active peptide or protein to an inert polypeptide, e.g., XTEN [17] (also known as recombinant PEG or "rPEG"), a homoamino acid polymer (HAP; HAPylation [27]), a proline-alanine-serine polymer (PAS; PASylation [28]), or an elastin-like peptide (ELP; ELPylation $[29,30])$.

3. Increasing the hydrodynamic radius by chemical conjugation of the pharmacologically active peptide or protein to repeat chemical moieties, e.g., to PEG (PEGylation [1, 2, 11, 12]) or hyaluronic acid [31].

4. (a) Significantly increasing the negative charge of fusing the pharmacologically active peptide or protein by polysialylation [32]; or, alternatively, (b) fusing a negatively charged, highly sialylated peptide (e.g., carboxy-terminal peptide [CTP; of chorionic gonadotropin (CG) $\beta$-chain] [33]), known to extend the halflife of natural proteins such as human CG $\beta$-subunit, to the biological drug candidate $[34,35]$.

5. Binding non-covalently, via attachment of a peptide or protein-binding domain to the bioactive protein, to normally long-half-life proteins such as HSA [8, 9], human $\operatorname{IgG}[10]$, or possibly transferrin.

6. Chemical conjugation of peptides or small molecules to long-half-life proteins such as human IgGs [36, 37], Fc moieties [38], or HSA [39].

Only the peptide or protein genetic fusion approaches, outlined above (1, 2, and $4 \mathrm{~b})$ and summarized in Table 2, are described in this paper. There are several other recent 
Table 2 Examples of half-life-extension strategies employing polypeptide fusions to small proteins and peptides to generate biobetters

\begin{tabular}{|c|c|c|c|}
\hline Strategy & $\begin{array}{l}\text { Specific } \\
\text { approach }\end{array}$ & Construct & $\begin{array}{l}\text { Mechanism for half-life } \\
\text { extension }\end{array}$ \\
\hline \multirow[t]{3}{*}{$\begin{array}{l}\text { Fusion to human protein with } \\
\text { inherently long serum half-life }\end{array}$} & $\begin{array}{l}\text { Fusion to } \\
\text { human } \\
\text { IgG Fc } \\
\text { domain }\end{array}$ & $\begin{array}{l}\text { Genetic fusion to } \mathrm{C} \text {-terminus or } \mathrm{N} \text { terminus of human } \\
\mathrm{IgG} \mathrm{Fc} \text {, which has a half-life of about } 14 \text { days in human } \\
\text { serum }\end{array}$ & $\begin{array}{l}\text { Recycling via FcRn } \\
\text { [43-46] }\end{array}$ \\
\hline & Fusion to HSA & $\begin{array}{l}\text { Genetic fusion to C-terminus or } \mathrm{N} \text { terminus of HSA, } \\
\text { which has } \sim 19 \text {-day half-life in human serum }\end{array}$ & $\begin{array}{l}\text { Recycling via FcRn } \\
{[45,47,48]}\end{array}$ \\
\hline & $\begin{array}{l}\text { Fusion to } \\
\text { human } \\
\text { transferrin }\end{array}$ & $\begin{array}{l}\text { Genetic fusion to } \mathrm{C} \text { terminus or } \mathrm{N} \text { terminus of human } \\
\text { transferrin, which has a } \sim 12 \text {-day half-life in human } \\
\text { serum }\end{array}$ & $\begin{array}{l}\text { Recycling via } \\
\text { transferrin receptor } \\
{[49]}\end{array}$ \\
\hline \multirow[t]{5}{*}{$\begin{array}{l}\text { Fusion to non-structured polypeptide } \\
\text { to increase overall size and } \\
\text { hydrodynamic radius }\end{array}$} & $\begin{array}{l}\text { XTENylation } \\
\text { (also known } \\
\text { as rPEG) }\end{array}$ & $\begin{array}{l}\text { Genetic fusion of non-exact repeat peptide sequence } \\
\text { (Amunix, Versartis) to therapeutic peptide }\end{array}$ & $\begin{array}{l}\text { Increase in size and } \\
\text { hydrodynamic radius } \\
\text { [17] }\end{array}$ \\
\hline & PASylation & $\begin{array}{l}\text { Genetic fusion of polypeptide sequences composed of } \\
\text { PAS (XL-Protein GmbH) forms uncharged random coil } \\
\text { structures with large hydrodynamic volume }\end{array}$ & $\begin{array}{l}\text { Increase in size and } \\
\text { hydrodynamic radius } \\
\text { [28] }\end{array}$ \\
\hline & ELPylation & $\begin{array}{l}\text { Genetic fusion to ELP repeat sequence (PhaseBio) can } \\
\text { extend half-life }\end{array}$ & $\begin{array}{l}\text { Increase in size and } \\
\text { hydrodynamic radius } \\
{[29,30,50]}\end{array}$ \\
\hline & HAPylation & HAP (e.g., homopolymer of glycine residues) & $\begin{array}{l}\text { Increase in size and } \\
\text { hydrodynamic radius } \\
\text { [27] }\end{array}$ \\
\hline & GLK fusion & Fusion with artificial GLK & $\begin{array}{l}\text { Increase in size and } \\
\text { hydrodynamic radius } \\
\text { [51] }\end{array}$ \\
\hline $\begin{array}{l}\text { Fusion to highly anionic polypeptide } \\
\text { to increase negative charge }\end{array}$ & CTP fusion & $\begin{array}{l}\text { Genetic fusion of CTP peptide from human CG } \beta \text {-subunit } \\
\text { to antibody fragment (Prolor Biotech) }\end{array}$ & $\begin{array}{l}\text { Increase in negative } \\
\text { charge via sialylation } \\
\text { of CTP }[34,35]\end{array}$ \\
\hline
\end{tabular}

$C G$ chorionic gonadotropin, CTP carboxy-terminal peptide, ELP elastin-like peptide, $F c$ constant fragment, $F c R n$ neonatal Fc receptor, $G L K$ gelatin-like protein, HAP homo-amino acid polymer, $H S A$ human serum albumin, $I g$ immunoglobulin, $P A S$ proline-alanine-serine polymer, $r P E G$ recombinant poly-ethylene glycol, XTEN genetic fusion of non-exact repeat peptide sequence

reviews on this general topic [3, 11, 40-42] that can be accessed for additional information.

\section{Fusion of Pharmacologically Active Moiety to Naturally Long-Half-Life Proteins}

\subsection{FcRn and its Effect on the Pharmacokinetics of IgG Fc-Based and Albumin-Based Fusion Proteins}

The half-life of peptides and proteins in human serum is dictated by several factors, including size, charge, proteolytic sensitivity, nature of their biology, turnover rate of proteins they bind, and other factors [5]. In some cases, the half-life of proteins in human serum can be roughly correlated with their size, as shown in Table 3. As mentioned previously, peptides and proteins smaller than approximately $70 \mathrm{kDa}$ can be eliminated via kidney filtration, so they generally possess very short serum half-lives. Larger proteins, however, may persist for several days. Three types of proteins-human IgGs, HSA, and transferrinpersist for much longer in human serum than would be predicted just by their size (Table 3 ). The exaggerated persistence of human IgGs and HSA has been determined to be due to their binding to the neonatal $\mathrm{Fc}$ receptor ( $\mathrm{FcRn}$ $[44,45])$, whereas the clathrin-dependent transferrin receptor-elongated half-life of transferrin [49] is described separately in Sect. 4.4.

$\mathrm{FcRn}$ is a heterodimeric receptor, closely related to major histocompatibility complex (MHC) class I receptors [45], which is widely expressed in vascular epithelial cells, endothelial cells, intestinal epithelial cells, mammary epithelial cells, placental membranes, monocytes, macrophages, dendritic cells, and polymorphonuclear (PMN) leukocytes. FcRn contains a $45 \mathrm{kDa}$, transmembrane $\alpha$ chain with a short cytoplasmic tail, and a $\sim 17 \mathrm{kDa} \beta-2$ microglobulin $\beta$-chain [43-46]. While FcRn functions to translocate IgGs from the mother to the fetus, it also has a significant function in both $\operatorname{IgG}$ and HSA homeostasis. 
Table 3 Nominal half-life values of human proteins in human serum

\begin{tabular}{|c|c|c|c|}
\hline Protein & $\begin{array}{l}\text { Nominal half-life } \\
\text { (hours) }\end{array}$ & $\begin{array}{l}\text { Molecular mass } \\
(\mathrm{kDa})\end{array}$ & $\begin{array}{l}\text { Ratio of half-life to molecular } \\
\text { mass }\end{array}$ \\
\hline HSA & 456 & 67 & 6.8 \\
\hline Transferrin & 288 & 80 & 3.6 \\
\hline $\operatorname{IgG}_{1}, \mathrm{IgG}_{2}, \mathrm{IgG}_{4}$ & 480 & 146 & 3.3 \\
\hline $\mathrm{IgG}_{3}$ & 144 & 165 & 0.87 \\
\hline IgA monomer & 120 & 160 & 0.75 \\
\hline $\begin{array}{l}\text { Retinol-binding } \\
\text { protein }\end{array}$ & 12 & 21 & 0.57 \\
\hline Factor $\mathrm{H}$ & 87 & 155 & 0.56 \\
\hline Factor XIII & 168 & 320 & 0.5 \\
\hline C-reactive protein & 48 & 125 & 0.38 \\
\hline Factor IX & 22 & 57 & 0.38 \\
\hline Fibrinogen & 100 & 340 & 0.29 \\
\hline IFN- $\alpha$ & 5 & 19 & 0.26 \\
\hline $\operatorname{IgE}$ & 48 & 188 & 0.25 \\
\hline Pentameric IgM & 144 & 970 & 0.15 \\
\hline IL-2 & 1.7 & 15 & 0.11 \\
\hline Thyroglobulin & 65 & 660 & 0.1 \\
\hline G-CSF & 2 & 20 & 0.1 \\
\hline Factor VIIa & 3 & 50 & 0.06 \\
\hline PYY3-36 & 0.13 & 4 & 0.03 \\
\hline IGF-1 & 0.17 & 8 & 0.02 \\
\hline hGH & 0.3 & 22 & 0.014 \\
\hline GLP-1 & 0.03 & 4 & 0.008 \\
\hline
\end{tabular}

$\overline{G-C S F}$ granulocyte colony-stimulating factor, $G L P$ glucagon-like peptide, $h G H$ human growth hormone, $H S A$ human serum albumin, IFN interferon, Ig immunoglobulin, IGF insulin-like growth factor, $I L$ interleukin, $P Y Y$ peptide tyrosine tyrosine
Upon pinocytosis of serum proteins by cells of the reticuloendothelial system, human $\mathrm{IgG}_{1}, \mathrm{IgG}_{2}$, and $\mathrm{IgG}_{4}$ isotypes and HSA bind FcRn in a pH-dependent manner. As the vesicles are acidified, the IgGs and HSA bind FcRn, which allows them to be translocated back to the cell surface for recycling back into the circulation, while non-FcRn-bound proteins are targeted for lysosomal degradation. Upon exposure to the neutral $\mathrm{pH}$ at the cell surface, the IgGs and HSA are released back into the circulation [43, 44]. This recycling mechanism confers a nominal 14- to 21-day halflife on human $\operatorname{IgG}_{1}, \mathrm{IgG}_{2}$, and $\mathrm{IgG}_{4}$, and a $~ 19$-day halflife on HSA [43-48]. Human $\operatorname{IgA}, \operatorname{IgM}, \operatorname{IgD}$, and $\operatorname{IgE}$ do not bind FcRn and do not possess an extended half-life, and human $\mathrm{IgG}_{3}$ has an altered residue in the FcRn-binding domain, which decreases its ability to bind FcRn, resulting in a diminished half-life of $\sim 5-7.5$ days [52]. The IgGs bind to FcRn at a different epitope than HSA, so the molecules do not compete [48]. Chaudhury et al. [47] calculated that for every $\operatorname{IgG}$ molecule recycled by FcRn, approximately 700 molecules of HSA are recycled. Thus, FcRn plays a significant role in the homeostasis of both human IgGs and HSA, the most abundant proteins in human serum. These properties have been used many times to improve the in vivo pharmacokinetics of otherwise short-lived peptides and proteins, as documented in the next few sections.

\subsection{Fc Fusion to Make Biobetters}

As mentioned above, human IgG isotypes 1, 2, and 4 bind to FcRn in a $\mathrm{pH}$-dependent manner to effect their recycling by epithelial cells $[43,44]$. This binding occurs via specific residues in the $\mathrm{Fc}$ of the antibody, giving these $\mathrm{IgG}$ isotypes a nominal 2- to 3-week half-life in human serum [53]. The concept of using IgG Fc as a fusion partner to significantly increase the half-life of a therapeutic peptide or protein has been around since the late 1980s, when Capon et al. [54] described the first Fc fusion protein (which they called an "immunoadhesin"), made by fusing the Fc portion of IgG to the exodomain of cluster of differentiation (CD)-4. Enbrel $^{\circledR}$ (etanercept), the first Fc fusion protein to be marketed, was approved in 1998, and many Fc fusion proteins have been described since [21-23, $53,55]$. 
Many Fc fusion proteins of various types have been made over the past 35 years, virtually all of which were intended to prolong the half-life of a protein or peptide. As of May 2015, $11 \mathrm{Fc}$ fusion proteins of various types had been approved for marketing by the FDA (Table 4). Eight of these were first-generation, innovative drugs, in which the Fc moiety was fused to a protein or peptide to enhance its pharmacokinetics (Table 4). On the other hand, three of the more recent $\mathrm{Fc}$ fusion proteins-Eloctate ${ }^{\circledR}$, Alprolix ${ }^{\circledR}$, and Trulicity ${ }^{\circledR}$-all approved by the FDA in 2014, are "biobetters" (Table 4), as described in the following sections. Strohl and Strohl [53] reviewed 27 different Fc fusion proteins, most of them innovative, which are either approved for marketing (e.g., Enbrel ${ }^{\circledR}$, Amevive ${ }^{\circledR}$, and Orencia ${ }^{\circledR}$ ) or are in clinical trials. There are several other recent reviews on Fc fusion proteins and peptides [21-23, 55-57]. Since the field of Fc fusions is so expansive, the remainder of this section is devoted only to those $\mathrm{Fc}$ fusions that are potential biobetter drugs in development.

\subsubsection{The Examples of Eloctate ${ }^{\circledR}$ and Alprolix ${ }^{\circledR}$}

Syntonix Pharmaceuticals, acquired by Biogen Idec in 2007, developed a technology for making monomeric $\mathrm{Fc}$ fusion molecules, in which a therapeutic protein is attached to only one arm of a dimeric Fc. The resultant protein is monovalent for the pharmacologically active "head" moiety but retains the normal bivalent Fc structure and function $[58,59]$. Biogen has used the monomeric protein-Fc technology to develop a whole series of potential extended-half-life biologics, including IFN- $\beta-F c$, IFN- $\alpha-F c$, epoetin-Fc, B-domain-deleted Factor VIII-Fc, and Factor IX-Fc. Two of these monomeric $\mathrm{Fc}$ fusion proteins were approved by the FDA in 2014: Alprolix ${ }^{\circledR}$ (eftrenonacog- $\alpha$; monomeric Factor IX-Fc of approximately $98 \mathrm{kDa}$ ) and Eloctate $^{\circledR}$ (efraloctocog- $\alpha$; monomeric B-domain-deleted Factor VIIIFc of approximately $220 \mathrm{kDa}$ ) (Table 4).

In clinical trials, Factor IX-Fc (Alprolix ${ }^{\circledR}$ ) was shown to have a terminal half-life in the range of 57-83 h, which was about threefold longer than the half-life of $\sim 18 \mathrm{~h}$ obtained with other formulations of Factor IX alone [60, 61]. This is comparable to the clinical trial data on the halflife of 89-96 h for recombinant Factor IX (rFIX)-FP, an rFIX-HSA fusion protein in phase 3 clinical development by CSL Behring $[62,63]$. For Factor VIII $\left(\right.$ Eloctate $\left.^{\circledR}\right)$, the Fc fusion improved the half-life by only about $50 \%$ from a range of $\sim 12 \mathrm{~h}$ for historical Factor VIII preparations to about $19 \mathrm{~h}$ for Factor VIII-Fc [64].

\subsubsection{The Example of Trulicity ${ }^{\circledR}$ (Dulaglutide)}

Pharmacologically active peptides, which typically have sequences of 40-50 amino acids or shorter, typically have very short half-lives in human serum (Table 3), often because of both enzymatic inactivation and glomerular filtration by the kidney. These peptides include peptide tyrosine tyrosine (PYY), neuropeptide Y (NPY), GLP-1, GLP2 , oxyntomodulin, pancreatic polypeptide, gastrin, and others $[65,66]$. Thus far, of these various incretins, only the GLP-1 pathway has been converted from the laboratory into a drug. Natural GLP-1 has a half-life in serum of about $2 \mathrm{~min}$ (Table 3), so in its native form, it could never be a drug. Three peptide-based drugs-Byetta ${ }^{\circledR} /$ Bydureon ${ }^{\circledR}$ (exenatide), Victoza ${ }^{\circledR} /$ Saxenda ${ }^{\circledR}$ (liraglutide), and Lyxumia ${ }^{\circledR}$ (lixisenatide)-are GLP-1 receptor agonists (Table 5). Liraglutide, which is an acylated form of DPP-4-resistant GLP-1 (containing GLP-1 amino acid residues 7-37), has a half-life in human serum of about $13 \mathrm{~h}$. Exenatide and lixisenatide are exendin- 4 analogs; exendin-4 is a DPP-4resistant peptide, originally isolated from the saliva of the Gila monster lizard (Heloderma suspectum), which possesses both a structure and activity highly similar to human GLP-1 [67]. Exenatide is the synthetic form of exendin-4 used in these drugs. These peptides have half-lives of a few hours in human serum (Table 5).

A GLP-1-Fc fusion protein designed and developed by Eli Lilly possesses the activity of GLP-1 with a serum halflife of 4-5 days, which supports once weekly dosing (Table 5). This Fc fusion protein contains a DPP-4-resistant version of GLP-1 (V8-GLP-1) fused to the Fc of a human $\operatorname{IgG}_{4}(\mathrm{~F} 234 \mathrm{~A} / \mathrm{L} 235 \mathrm{~A})$ via a linker [68]. The length and structure of the linker was found to be a critical component of the design, because in the absence of the linker, the GLP-1 agonist activity was minimal [68]. The Eli Lilly GLP-1 Fc fusion protein, marketed under the name Trulicity ${ }^{\circledR}$ (dulaglutide), was approved by the FDA in September 2014 (Table 4). A similar GLP-1 Fc ( $\operatorname{IgG}_{4}-$ ala-ala) fusion protein, known as the GLP-1-Mimetibody $^{\mathrm{TM}}$ construct, CNTO530 [76], was also designed and taken into phase 2 clinical trials by Centocor, but it was later dropped. Similarly, a GLP-1 fusion with the Fc of an $\mathrm{IgG}_{2}$ was recently published [77]. A critical point for all three of these constructs is that the $\mathrm{Fc}$ moieties were designed for minimal $\mathrm{Fc}$ activity, as opposed to using the $\mathrm{Fc}$ of an $\mathrm{IgG}_{1}$, which could result in effector function activity and potentially killing activity toward the target cells possessing the GLP-1 receptor (GLP-1R). The importance of the silent or muted $\mathrm{Fc}$ has been discussed in further detail by Strohl and Strohl [53].

There are four examples shown in Table 6 of potential biobetter $\mathrm{Fc}$ or IgG fusion protein candidates. An interleukin (IL)-2-anti-GD-2 antibody fusion currently in phase 2 clinical development by researchers at the National Cancer Institute is a potential biobetter of Proleukin ${ }^{\circledR}$ by virtue of the anti-GD-2 targeting. Similarly, the IL-2 fusion protein with an anti-tenascin $\mathrm{C}$ single-chain variable 


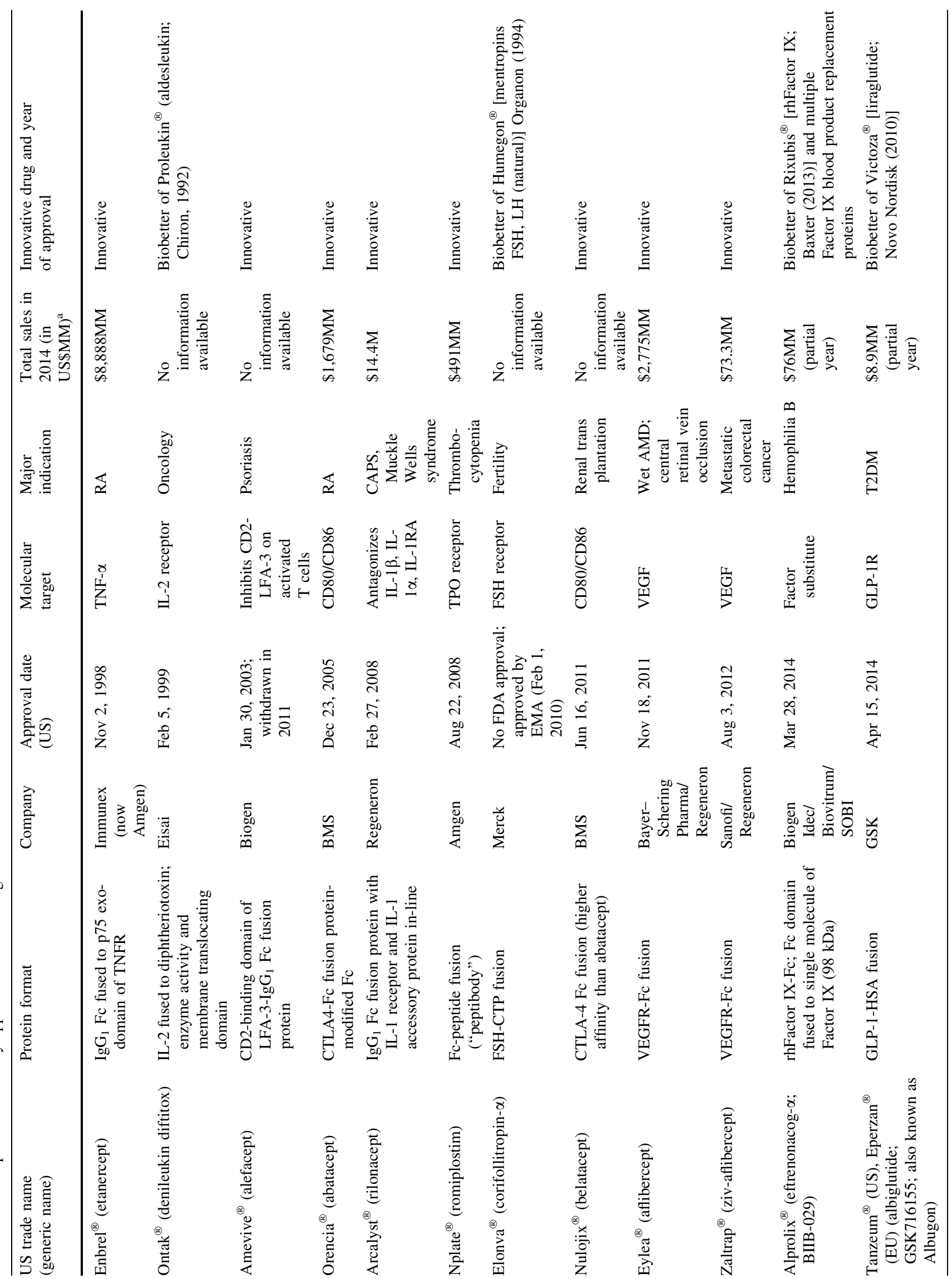




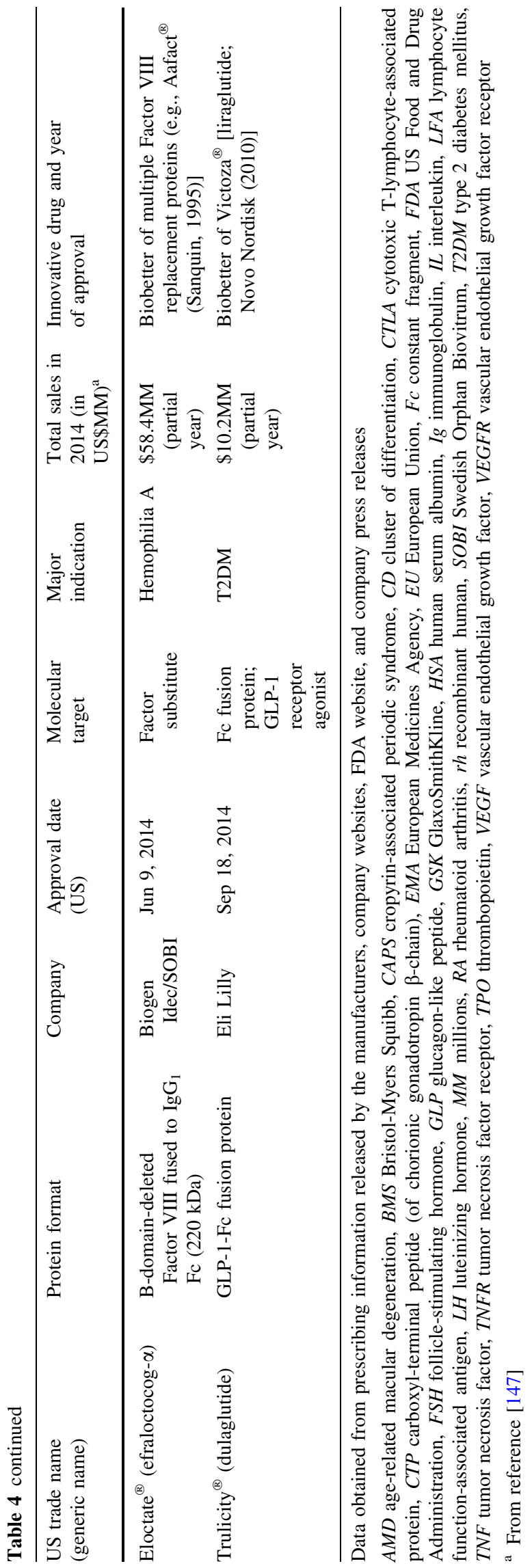

fragment ( $\mathrm{scFv}$ ), in phase $1 / 2$ clinical trials by Philogen, is a biobetter because of targeting rather than half-life extension. Two other programs in the preclinical space include the recombinant Factor VIIa-Fc fusion [78] being developed by Biogen Idec and Swedish Orphan Biovitrum (SOBI), and a recombinant von Willebrand factor domains $\mathrm{D}^{\prime}$ and D3-Fc fusion [79] for treatment of patients with hemophilia A. In this last case, if the novel fusion molecule were developed, it would replace a plasma-derived product.

\subsection{Albumin Fusion}

The $66.5 \mathrm{kDa}$ protein HSA, similar to human IgGs, has a long average half-life in the 19-day range (Table 3). At a concentration of $\sim 50 \mathrm{mg} / \mathrm{mL}(\sim 600 \mu \mathrm{M})$, HSA is the most abundant protein in human plasma, where it has several functions, including maintenance of plasma $\mathrm{pH}$, metabolite and fatty acid transport, and a role in maintaining blood pressure. HSA, which is at the upper limit of size for glomerular filtration of proteins by the kidney, is strongly anionic, which helps even more to retard its filtration via the kidney [1]. Like IgGs, HSA also binds FcRn in a pH-dependent manner [47], albeit at a site different from-and via a mechanism distinct from-that of $\operatorname{IgG}$ binding [48], and is recycled similarly to IgGs, resulting in its extended half-life [44, 48]. HSA also tends to accumulate in tumors and in inflamed tissues, which suggests that fusion or binding to albumin may potentially help to target proteins or peptides to those sites [89].

The fusion of peptides or proteins with inherently shorthalf-life properties to HSA for prolongation of the serum half-life has been investigated broadly since the early 1990s, after Yeh et al. [90] published a paper documenting the 140-fold improvement in half-life of a CD4 exodomain-HSA fusion over that of CD4 exodomain alone. The biotechnology company Principia Pharmaceuticals was spun out with the intellectual property for HSA fusion protein technology in the late 1990s from Aventis Behring, the forerunner to today's CSL Behring. Shortly afterwards, Principia was acquired by Human Genome Sciences in September 2000 [91]. Since then, dozens of different peptides and small proteins have been fused to HSA as both innovative and potential biobetter molecules, as reviewed by several authors [25, 26, 89, 92-96]. Companies leading the way with HSA fusion technology include GlaxoSmithKline (which obtained rights when they acquired Human Genome Sciences in 2012), Teva (which obtained rights upon acquisition of the HGS spin-off), Cogenesis, and CSL Behring.

The first HSA-peptide or protein fusion product to be approved for marketing is Tanzeum ${ }^{\circledR}$ (marketed as Eperzan ${ }^{\circledR}$ in the European Union) a DPP-4-resistant GLP- 


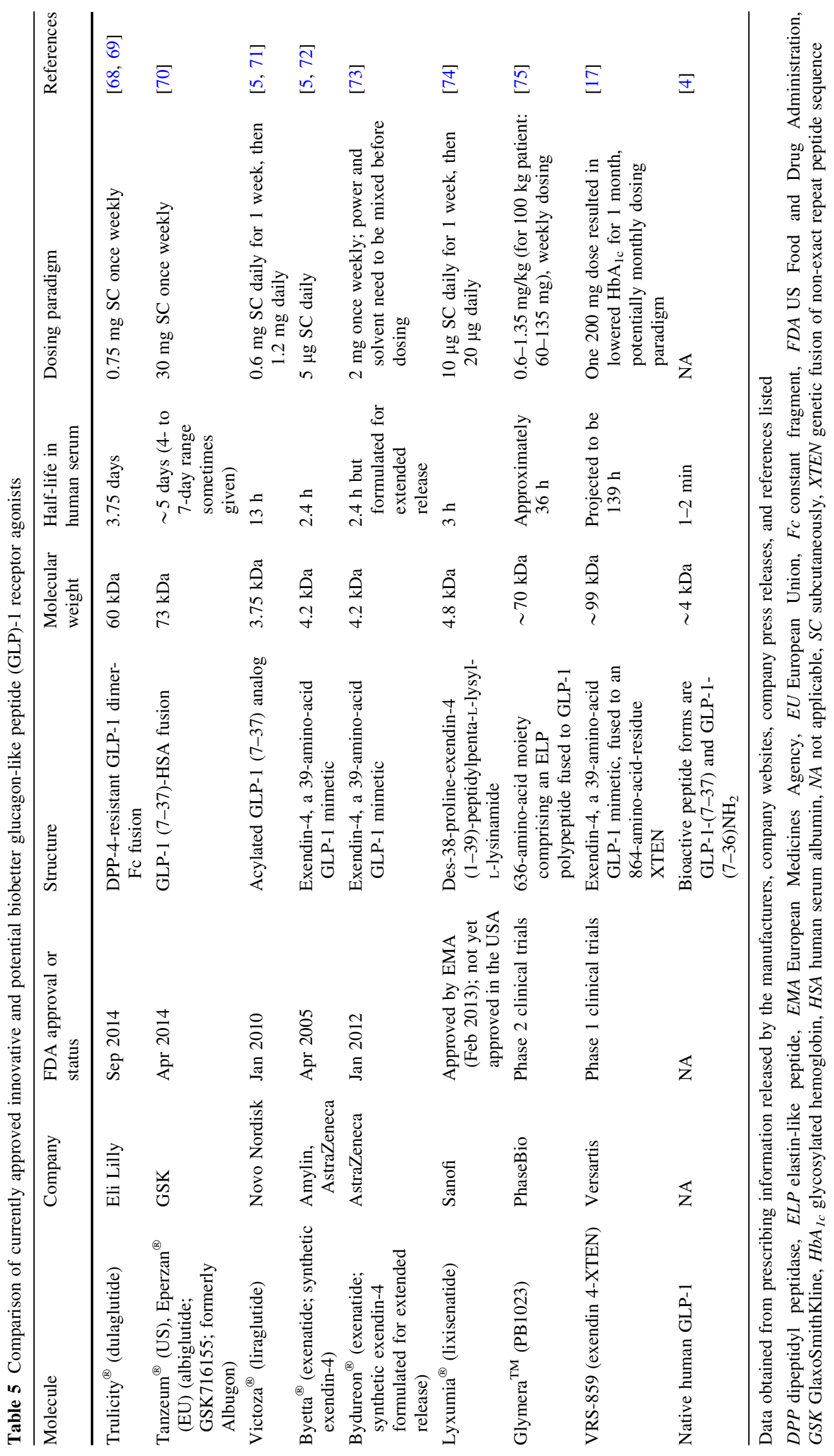




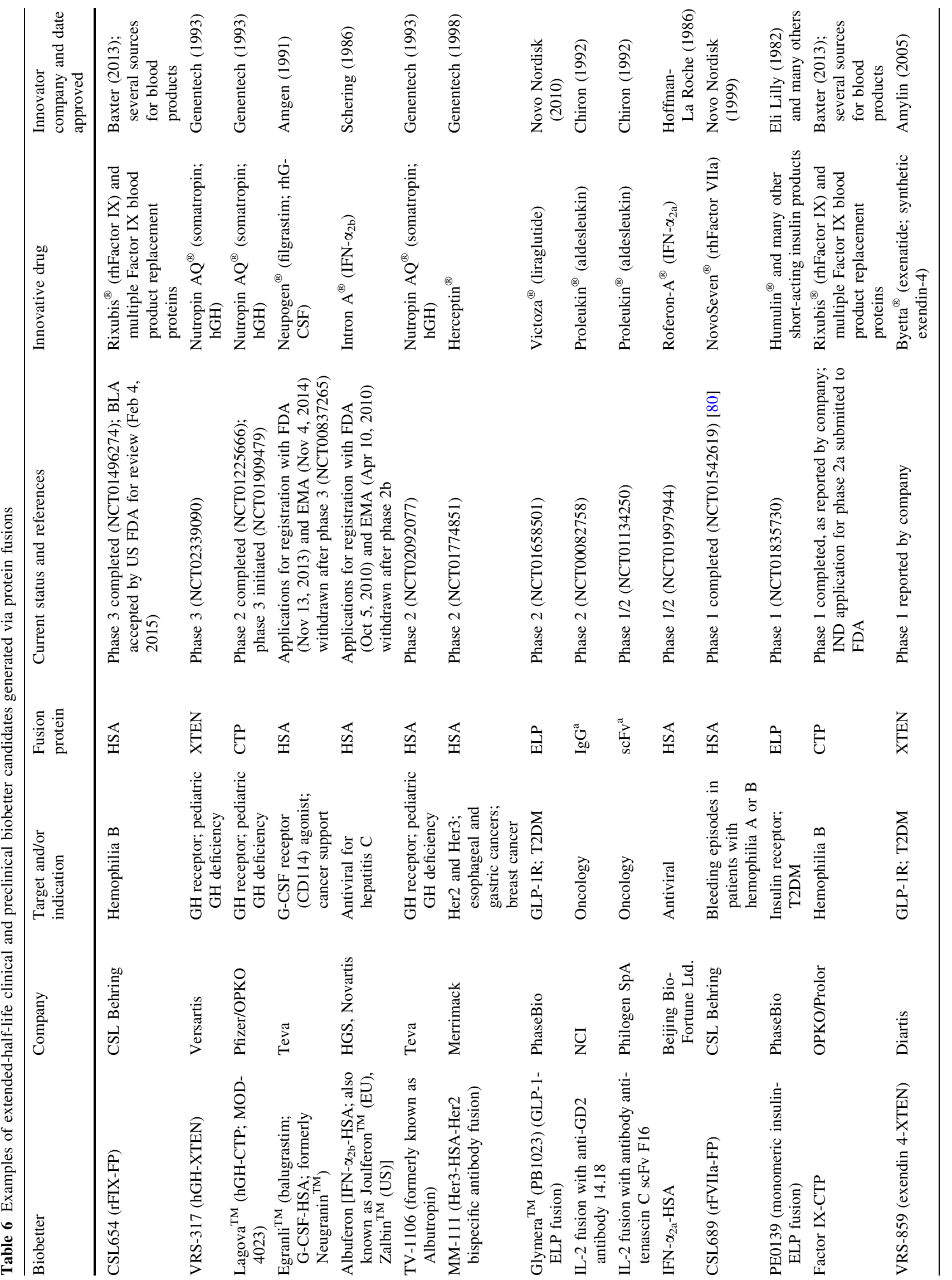




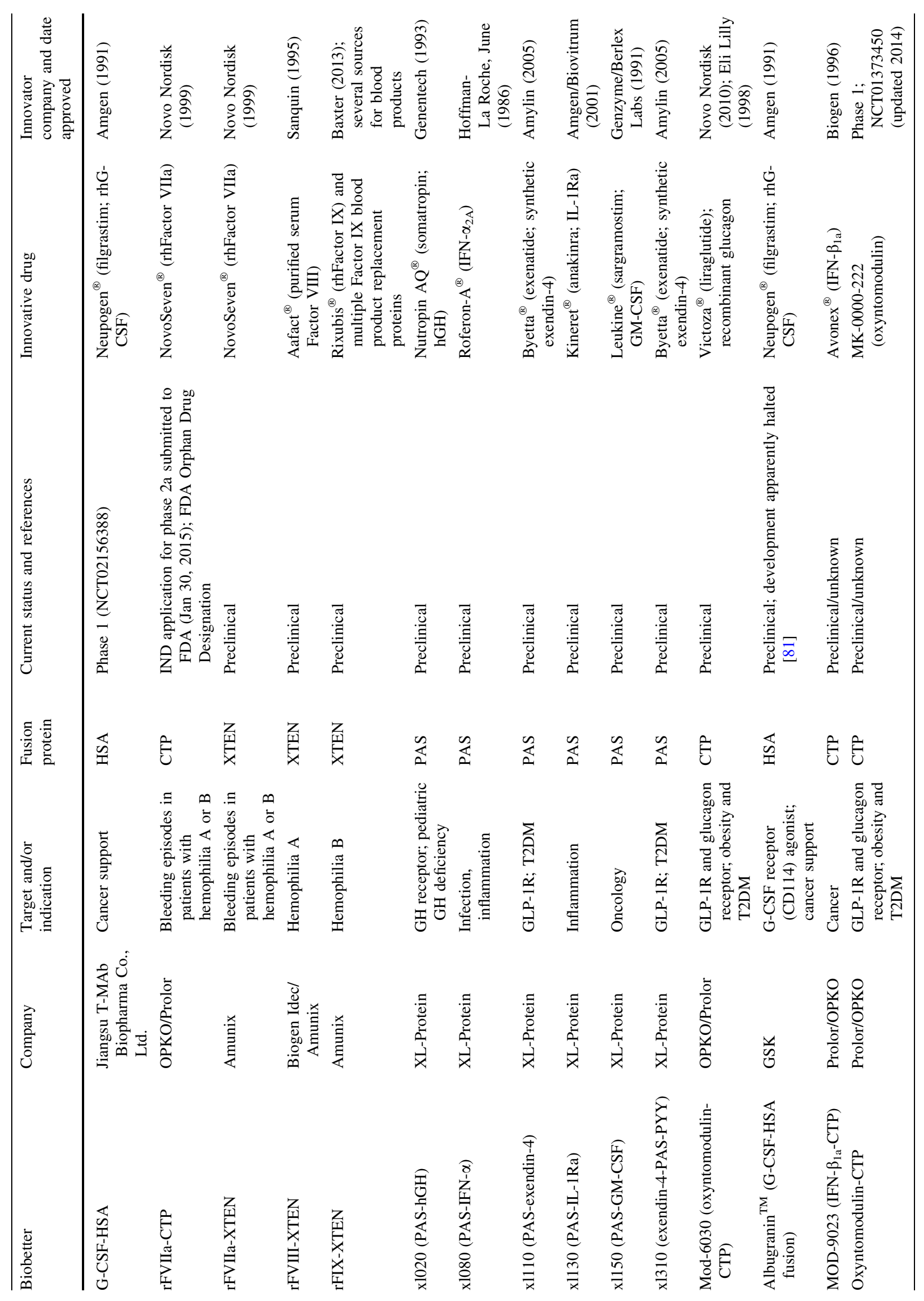




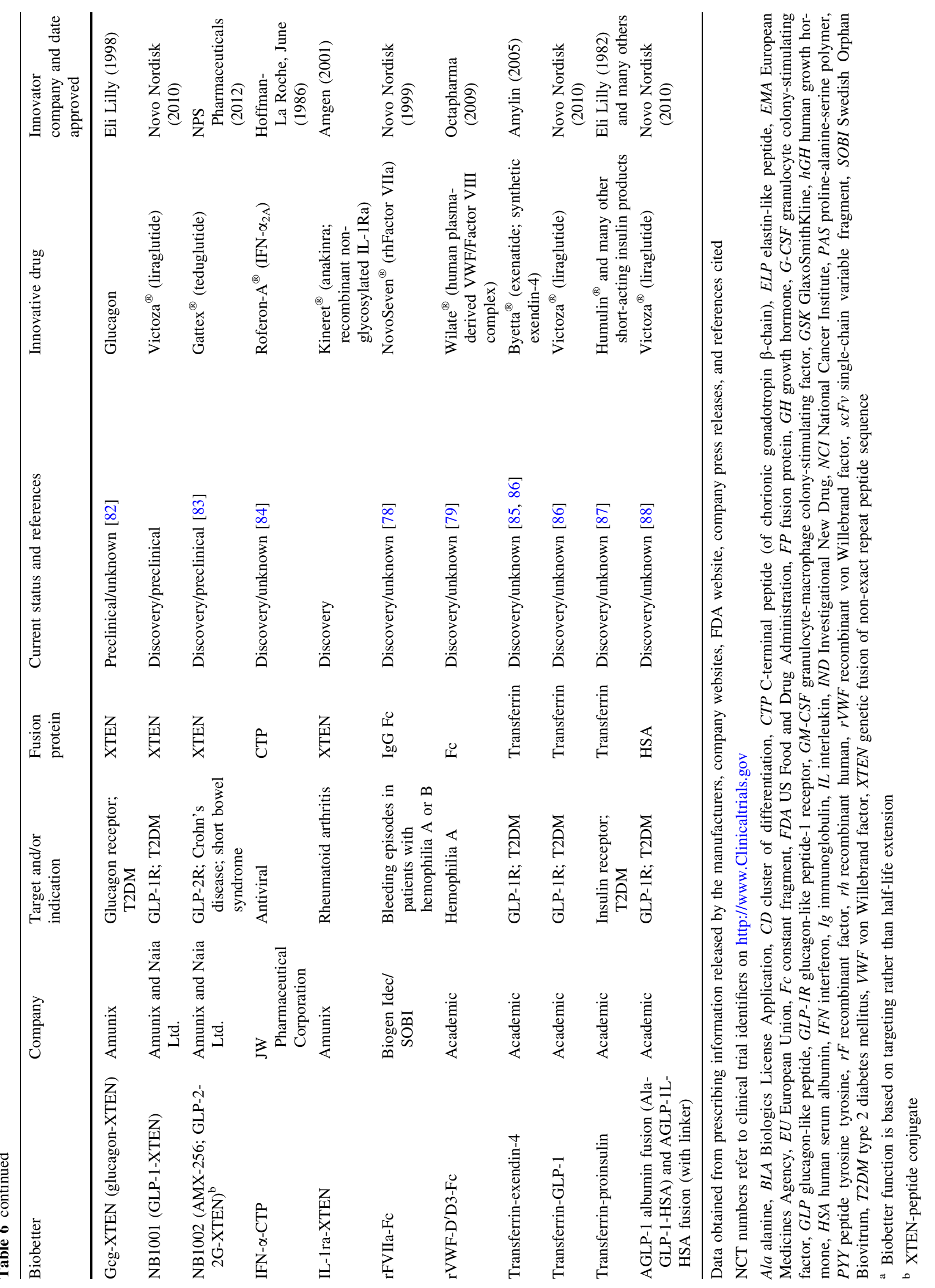


1-HSA fusion protein discovered at Human Genome Sciences and developed and marketed by GlaxoSmithKline. Tanzeum $^{\circledR}$ (albiglutide), which was approved by the European Medicines Agency (EMA) and the FDA in March and April 2014, respectively (Table 4), improves the half-life of pharmacologically active GLP-1 from 1-2 min for native GLP-1 (Tables 3, 5) to 4-7 days, which allows for once weekly dosing (Table 5). Tanzeum ${ }^{\circledR}$ is a biobetter version of the first generation of GLP-1 receptor agonists such as liraglutide. It is a direct competitor with dulaglutide, described above, for the once weekly dosing T2DM market. As shown in Table 6, there are at least eight additional preclinical or discovery-stage fusion proteins with either GLP-1, exendin-4, or the dual GLP-1R/glucagon receptor agonist, oxyntomodulin, that could potentially be biobetters of liraglutide.

Table 6 lists seven other known HSA fusion protein product candidates that are either now in development or recently have been in development. The most advanced of these is CSL654 (also known as rFIX-FP [97]), which has completed phase 3 clinical trials. CSL Behring, which is developing CSL654, submitted a Biologics License Application (BLA) to the FDA in December 2014. If approved for marketing, CSL654 will become a biobetter version of Baxter's Rixubis ${ }^{\circledR}$, an rhFactor IX, which was just recently approved by the FDA in 2013. CSL654 (rFIXFP) demonstrated a terminal half-life in humans of 89-96 h $[62,63]$, which compared very favorably with the half-life of the FIX-Fc fusion protein, Alprolix ${ }^{\circledR}$, which had a terminal half-life of 57-83 h [60].

Another significant HSA fusion protein in clinical studies is hGH-HSA fusion. This fusion protein, once known as Albutropin [98], was developed preclinically by Human Genome Sciences but is now being developed clinically by Teva, which acquired the asset when it acquired the HGS spin-off company Cogenesis in 2008. TV-1106, formerly called Albutropin, is now in phase 2 clinical trials (Table 6).

Not all HSA fusions have fared well in clinical trials. The development of two different forms of G-CSF-HSA fusions, Egranli $^{\mathrm{TM}}$ (also known as balugrastim and Neugranin ${ }^{\mathrm{TM}}$ ) and albugranin, has been halted. Egranli ${ }^{\mathrm{TM}}$ was taken into late-stage clinical development by Teva and submitted to both the EMA and FDA for marketing, but the applications were recently withdrawn (Table 6). A third G-CSF-HSA fusion protein, sponsored by Jiangsu T-MAb Biopharma Co., Ltd., is still in phase 1 clinical development. Similarly, an IFN- $\alpha_{2 b}$-HSA fusion protein [99] known as albuferon (also known as Joulferon ${ }^{\mathrm{TM}}$ and Zalbin ${ }^{\mathrm{TM}}$ ) was under development by Human Genome Sciences and Novartis for treatment of patients with hepatitis C [100]. Albuferon was discontinued from development in 2010 because of its questionable safety profile.
A very interesting bispecific antibody-HSA fusion protein, MM-111, is currently in phase 2 clinical development by Merrimack. The protein is a fusion of an anti-Her3 (ErbB3) scFv antibody-HSA-anti-Her2 (ErbB2) scFV (Table 6), which is being developed for the treatment of breast, esophageal, gastric, and other Her2-positive cancers. The HSA confers on the scFvs (which normally have a half-life as free scFvs of $<1 \mathrm{~h} \mathrm{[53])} \mathrm{a} \mathrm{half-life} \mathrm{of} \mathrm{86-90} \mathrm{h}$ [101]. If this protein is eventually approved for marketing, it may be a biobetter version of Genentech's Herceptin ${ }^{\circledR}$, which was first approved for marketing in 1998. In this case, the biobetter property would not be half-life extension but, rather, the addition of the second antibody, anti-Her3, which gives it added activity, especially in cancers expressing high levels of heregulin [102].

Two other HSA fusion biobetter proteins are currently known to be in clinical development (Table 6): IFN- $\alpha_{2 a^{-}}$ HSA fusion (sponsored by Beijing Bio-Fortune Ltd.), which is in phase 1/2 trials, and CSL689 (rFVIIa-FP), a Factor VIIa-HSA fusion protein for treatment of hemophilia A or B patients with bleeding episodes. The IFN$\alpha_{2 \mathrm{a}}$-HSA fusion protein would be a longer-half-life biobetter candidate for Roche's Roferon-A ${ }^{\circledR}$, while CSL689 would be a longer-half-life biobetter competitor for Novo Nordisk's NovoSeven ${ }^{\circledR}$ (Table 6). Finally, other HSA fusion proteins have been mentioned in the literature, including an IL-2-HSA fusion protein and a $\beta$-natriuretic peptide-HSA fusion protein, both of which were in development in the past but have apparently been discontinued.

Novozymes, a protein engineering company in Denmark, has been developing modified versions of recombinant HSA with improved FcRn binding for construction of "next-generation" HSA-protein fusions that may possess even longer half-life properties. A K573P mutant of HSA, which was found to possess 12-fold greater affinity for FcRn, conferred a longer half-life on HSA than wild type in both mice and cynomolgus monkeys [103]. The expectation is to use these longer-half-life mutants of HSA as fusion proteins to improve the half-life of fusion proteins even further.

\subsection{Transferrin Fusion}

Transferrin is a highly abundant serum glycoprotein, found in serum at $3-4 \mathrm{mg} / \mathrm{mL}$, which binds iron tightly but reversibly and functions to carry iron to tissues. Transferrin has 679 amino acid residues, is about $80 \mathrm{kDa}$ in size, and possesses two high-affinity $\mathrm{Fe}^{3+}$-binding sites, one in the $\mathrm{N}$-terminal domain and the other in the $\mathrm{C}$-terminal domain [104]. Human transferrin has a half-life reported to be 7-10 days [86] or 10-12 days [11]. The aglycosylated form of human transferrin, which makes up about 2-8\% of the total transferrin pool, has a slightly longer half-life of 
14-17 days [86]. The extended persistence of transferrin in human serum is due to a clathrin-dependent transferrin receptor-mediated mechanism, which recycles transferrin receptor-bound transferrin back into the circulation [49, 105].

Fusions of peptide and proteins have been made to human transferrin to the $\mathrm{N}$ - and $\mathrm{C}$ - termini, as well as to the centrally located hinge region that links the two major lobes of transferrin together. The $\mathrm{N}$ terminus of transferrin is free and can be fused directly. The $\mathrm{C}$ terminus is more buried and is constrained by a nearby disulfide bond, so flexible linkers are typically used when proteins are fused to the $\mathrm{C}$ terminus. This capability was extended by making libraries of peptides against specific targets and then fusing binders from those libraries into aglyco-transferrin (N-terminal, C-terminal, loops, or linker region) to be developed into therapeutic fusion proteins with extended half-lives [106].

The biotechnology company BioRexis Technologies, Inc., was founded in 2002 to develop the transferrin fusion protein platform, which they termed the "Trans Body" platform, as a therapeutic platform. Their lead molecule, BRX-0585, was a transferrin-GLP-1 fusion protein for treatment of type 2 diabetes mellitus (T2DM). Fusion of GLP-1 to transferrin was demonstrated to significantly enhance the half-life of GLP-1. BioRexis was acquired by Pfizer in March 2007. As far as can be determined, no BioRexis-derived fusion proteins are currently in the clinic.

Bai et al. [107] reported the construction of a human G-CSF-transferrin fusion protein with oral bioavailability in mice. When the G-CSF-Tf fusion protein was administered orally, pharmacodynamic activity was observed for 3 days, as compared with only a single day of pharmacodynamic effects after subcutaneous injection.

A few recent reports have suggested that transferrin fusion is still being considered for biobetters, as summarized in Table 6. Kim et al. [86] generated fusions of GLP1 and exendin-4 to a non-glycosylated form of human transferrin to produce longer-half-life versions of those metabolism-related peptides. Both molecules retained most of the activity of the native peptides while providing significant improvements in half-life. Matsubara et al. [108] also fused a DPP-4-resistant analog of GLP-1 to non-glycosylated transferrin and used the longer-half-life molecule to improve outcomes in myocardial ischemia/reperfusion models. This molecule improved the half-life of GLP-1 in rabbits from a few minutes to $27 \mathrm{~h}$ [108]. Very recently, an exendin-4-transferrin fusion was generated and produced in plants [85]. This plant-produced form of exendin-4-transferrin fusion was found to have some level of oral bioavailability, suggesting some promise as an orally delivered therapy [85].

Recently, a proinsulin-transferrin fusion prodrug was generated, which underwent a cleavage to bioactive insulin in hepatic cell culture in a transferrin receptor manner [87, 109]. The hypothesis for this activity was that transferrin receptor-mediated endocytosis resulted in intracellular cleavage of the proinsulin to the active insulin-transferrin fusion. In vivo studies, interestingly, demonstrated insulin activity of the insulin-transferrin fusion in liver but not skeletal muscle [87].

\section{CTP Fusion: Half-Life Extension Through Charge}

Another interesting peptide fusion approach has a very different mechanism of action. Thyroid-stimulating hormone (TSH; also known as thyrotropin) and the three gonadotropins, follicle-stimulating hormone (FSH), luteinizing hormone ( $\mathrm{LH})$, and $\mathrm{CG}$, are heterodimeric glycohormones consisting of a common $\alpha$-subunit and unique $\beta$-subunits, which confer on them their different activities [110]. The half-life of human CG (HCG) is significantly longer than that of its counterparts, $\mathrm{FSH}, \mathrm{LH}$, and TSH. The difference between HCG and its counterparts is that the HCG $\beta$-subunit (HCG- $\beta$ ) possesses a $\sim 31$-aminoacid-residue CTP consisting of the sequence FQSSSS* KAPPPS*LPSPS*RLPGPS*DTPILPQ, which possesses four $O$-glycosylation sites (denoted by $\mathrm{S}^{*}$ ) terminating with a sialic acid residue [111]. CTP has been demonstrated to naturally extend that protein's half-life in human serum, likely because the negatively charged, heavily sialylated CTP impairs renal clearance [34].

The CTP technology was developed for potential commercial use by Prolor Biotech, Inc., which was acquired by OPKO in August 2013. Over the past decade or so, CTP has been fused to several hormones, factors, and cytokines in an attempt to elongate their half-lives. CTP was genetically fused to the C-terminus of erythropoietin (EPO), resulting in a recombinant EPO-CTP that demonstrated a substantially improved half-life and improved in vivo potency over normal EPO [112].

FSH-CTP (corifollitropin- $\alpha$, Org 36286) was the first CTP fusion to be taken into clinical trials as a long-acting FSH for treatment of infertility in women [33, 113]. FSH-CTP consistently demonstrated about a twofold improvement in halflife over recombinant FSH, no matter whether it was dosed subcutaneously or intravenously [33, 112]. The FSH-CTP fusion protein (Org 36286) was approved by the EMA in February 2010 as a long-acting fertility drug named Elonva ${ }^{\circledR}$ (corifollitropin- $\alpha$ [114]), marketed by Merck and Co. Elon$\mathrm{va}^{\circledR}$ has not been approved by the FDA.

Besides Elonva ${ }^{\circledR}$, at least three other CTP fusion proteins are in clinical trials (Table 6). CTP has also been genetically fused with hGH to make a long-acting hGHCTP chimera (Lagova $^{\mathrm{TM}}$; MOD-4023), which had a 
substantially extended half-life and a greater AUC than hGH alone in rat models [115]. This translated into a 12-fold improvement in serum half-life in humans [116], as compared with a $\sim 3.4$-h half-life for recombinant hGH dosed subcutaneously in humans [117]. OPKO partnered Lagova $^{\text {TM }}$ (MOD-4023; hGH-CTP) with Pfizer in December 2014 for continued development and potential commercialization. Lagova ${ }^{\mathrm{TM}}$ is currently in phase 3 clinical trials for treatment of pediatric growth hormone deficiency (Table 6).

Additionally, a coagulation Factor IX-CTP fusion protein has been reported by OPKO to be in phase 1 clinical trials for treatment of hemophilia B, and a coagulation Factor VIIaCTP fusion protein is in preclinical studies at OPKO for treatment of bleeding episodes with hemophilia A or B (Table 6). Investigational New Drug (IND) applications have been filed with the FDA to initiate phase 2a clinical trials for both the Factor IX-CTP and Factor VIIa-CTP fusion proteins, and the Factor VIIa-CTP fusion protein has been granted an Orphan Drug Designation by the FDA.

Overall, it appears that fusion of CTP to a protein is likely to extend its half-life by two- to fourfold and perhaps more in isolated cases. Fusion of CTP to peptides appears to elongate their half-lives even more, although the published data are less well developed for this use. One significant limitation of this technology is that the recombinant CTP fusion must be produced in Chinese hamster ovary $(\mathrm{CHO})$ or other mammalian cell systems, so that the resultant recombinant proteins are $O$-glycosylated in the CTP extension module [35]. Whether CTP fusion to any particular peptide or small protein target will prove to significantly enhance its half-life is yet to be determined. Nevertheless, in a situation in which modest half-life extension is desired, along with a product that is negatively charged (because of the multiple sialylations), CTP fusions might be a valid approach.

OPKO/Prolor have generated other CTP fusions, including an IFN- $\beta$-CTP (MOD-9023), which they claimed in a press release to have 55-fold greater overall exposure over IFN- $\beta$ alone, as well as a CTP fusion with the anti-obesity peptide oxyntomodulin (Table 6), with claims of 100-fold more durability than the naturally occurring peptide. The status of those programs is unknown. Separately, JW Pharmaceutical Corporation constructed an IFN- $\alpha$-CTP fusion for use in antiviral indications [84], but nothing more is known about the current development of this protein.

Finally, in an effort to build a better vaccine, Tang et al. [118] generated a novel fusion of the hepatitis B virus (HBV) core 18-27 peptide (HBcAg18-27), which primes HLAclass I restricted immune responses in patients acutely infected with $\mathrm{HBV}$, with CTP and the endoplasmic reticulum chaperone tapasin to make the fusion HBcAg18-27-tapasinCTP. This construct, which strongly activated CD8+
$\mathrm{T}$ cells, was tested as a potential innovative target-specific immunogen for HBV vaccine design [118].

\section{Recombinant Polypeptide Chains}

While the use of PEG to increase the hydrodynamic radius of peptides or small proteins to increase their half-life in human serum remains a significant and clinically tested approach $[1,2,12]$, several new strategies have emerged as an alternative to chemical conjugation to PEG or other nonbiologic polymers. The common thread for all of these strategies is the fusion of inert peptide repeat polymers to the recombinant protein to be modulated. This approach might be viewed as a hybrid of the PEG conjugation approach and fusion to the naturally long-half-life proteins IgG Fc, albumin, or transferrin. This polypeptide fusion approach yields four immediate advantages over PEGylation: (1) the cost of the PEG moiety and the time and process cost for the chemistry to couple it to the protein are eliminated; (2) the entire construct can be made in a "single pot reaction" in Escherichia coli for many peptides and small proteins; (3) only a single round of purification is required rather than purification followed by conjugation and then repurification, as occurs with PEGylated proteins [15]; and (4) the peptides, while largely extracellular protease resistant, will be slowly degraded by natural processes in vivo. The two major potential drawbacks of these platforms are the potential for immunogenicity of the polypeptide repeat units and unknown factors, as compared with the much better-studied Fc and HSA fusions.

\subsection{XTEN}

In developing the Versabody scaffold, scientists at Amunix investigated the ability of an amino acid repeating polymer to extend the half-life of various versabodies and other small proteins. They generated a library of sequences containing the amino acid residues A, E, G, P, S, and T, and scored for expression in E. coli, followed by analysis for genetic stability, solubility, lack of aggregation, and heat stability [17]. From these data, several sequences, dubbed "XTEN" sequences, were tested for their ability to extend the half-lives of peptides such as exenatide and glucagon, and proteins such as green fluorescent protein (GFP) and hGH. XTEN lengths of 288 ( $32 \mathrm{kDa})$ to 1008 $(\sim 111 \mathrm{kDa})$ residues were tested in mouse, rat, and monkey models, resulting in half-life improvements ranging from 50- to 125-fold for the peptides in different animal models and up to $\sim 12$-fold for GFP [17]. Rabbit tests with GFP-XTEN demonstrated an immune response to the GFP but little or none to the XTEN moiety. In those experiments, the XTEN moiety also appeared to possess some 
level of shielding effect, similar to PEG. Recently, Geething et al. [82] tested glucagon fused with XTEN moieties ranging from 36 to 288 amino acid residues in length. The XTEN sequences ranged from inexact repeats of ... GSEGEG ... and similar sequences to much more highly randomized sequences containing longer inexact repeats of residues similar to ... AESPGPGTSPSGESSTAPGT ... [82]. They tested the pharmacodynamics of these constructs in fasted dogs and demonstrated that they could prevent hypoglycemia without inducing temporary hyperglycemia, an event often associated with glucagon alone. The sequence of their most optimized glucagon-XTEN compound designed to treat nocturnal hypoglycemia contained 144 amino acid residues fused to the C-terminus of glucagon [82].

There are currently nine known XTEN fusion programs that appear to be intended as biobetter programs (Table 6). The furthest along in development is VRS-317, which is a fusion of hGH and XTEN [119]. VRS-317, currently being developed by Versartis, is in phase 3 clinical trials (Table 6). VRS-317 was demonstrated to possess a 131-h half-life in humans [120], which is considerably longer than that of recombinant, subcutaneously dosed hGH [117] and much longer than that of the CTP-hGH fusion protein, MOD-4023 [116].

The only other XTEN fusion molecule currently in the clinic is VRS-859 (Table 5), a fusion of XTEN and exendin [17], which is currently in phase 1 clinical trials for glycemic control in patients with T2DM. Fusion of XTEN to exendin increased the half-life in rats and mice from 65 to 71-fold, and in monkeys from about $30 \mathrm{~min}$ to $60 \mathrm{~h}$ [17].

Additional Amunix preclinical XTEN biobetter programs, listed in Table 6, include gcg-XTEN (glucagonXTEN fusion [82]), IL-1ra-XTEN, and the coagulation factors rFVIIa-XTEN, rFVIII-XTEN, and rFIX-XTEN. Amunix partnered the rFVIII-XTEN program with Biogen Idec in April 2014, and partnered with Eli Lilly in December, 2014, for assets in the T2DM field. Amunix has also recently partnered two programs with Naia Limited, including NB1001 (GLP-1-XTEN) and NB1002 (AMX256; GLP-2-2G-XTEN [83]), the latter of which is an XTEN-peptide fusion. Other XTEN fusion proteins have been reported previously, including AMX-213 (a ghrelinXTEN fusion protein), AMX-888 (a C-peptide-XTEN fusion), and AMX-583 (an $\alpha$-1-anti-trypsin-XTEN fusion protein) [121], but no information is available on these candidates currently, suggesting that they may not be in active development.

\subsection{ELPylation}

A second method for half-life extension of peptides and proteins via polypeptide fusion is the use of ELPs, which are repeating peptide units containing sequences commonly found in elastin, for "ELPylation". The ELP sequence contains repeats of V-P-G-x-G, where $\mathrm{x}$ is any amino acid except proline $[29,30]$. The fact that this sequence can be degraded over time by human elastases makes ELP polymers biologically degradable. ELPylation is a process by which ELP repeat sequences are genetically fused to a target protein to enhance a thermally responsive phase transition $[29,30]$. Thus, at higher temperatures, above the so-called transition temperature, ELPs aggregate and fall out of solution. When the temperature is decreased below the transition point, they become fully soluble again. Modification of the " $\mathrm{x}$ " position, i.e., making it more or less polar or charged, alters the transition state of the polymer. This property has been exploited for protein purification and as a scaffold platform for tissue growth. It has also been demonstrated that fusion of ELP sequences to small therapeutic proteins enhances the half-life of those proteins by giving them a larger hydrodynamic radius and thus they are not eliminated by the kidney [50]. An anti-tumor necrosis factor (TNF)- $\alpha$ VHH (singledomain) antibody of about $12 \mathrm{kDa}$ was fused with ELP, resulting in a substantially increased half-life of the VHH protein in rodent models [50].

The biotechnology company PhaseBio (http://phasebio. com) is developing ELPylation as an aid in protein purification and as a half-life-extension module for innovative and biobetter product candidates. PhaseBio currently has three ELPylated products in clinical trials: (1) Glymera $^{\mathrm{TM}}$ (PB1023), an ELPylated, 636-amino-acid-long fusion with GLP-1, which is intended for once weekly dosing as a biobetter form of Victoza ${ }^{\circledR}$ [75] (Tables 5, 6) and is currently in phase 2 clinical trials (Table 6); (2) PE0139, an ELPylated form of insulin, which is intended to be a long-acting, biobetter form of Humulin ${ }^{\circledR}$ and other short-acting insulin products, and is currently in phase 1 clinical trials (Table 6); and (3) Vasomera ${ }^{\mathrm{TM}}$ (PB1046), an ELPylated fusion of vasoactive intestinal peptide (VIP; a naturally occurring 28 -amino-acid peptide), which appears to be an innovative drug candidate and is a selective VPAC2 receptor agonist, being developed as a weekly dosed treatment of cardiopulmonary diseases. Recent evidence, however, has demonstrated that superagonism of VPAC2 in mice is correlated with a significant risk of development of neurological disorders [122], suggesting caution in this approach.

\subsection{PASylation}

Another approach to using polypeptide repeat sequences is PASylation, which comes from the generation of a polymer using three repeating amino acids, proline, alanine and serine (i.e., PAS). PAS polymers of 100-200 repeats in length were shown to improve the pharmacokinetics of small proteins in mice by 3.5- to 6-fold over non- 
PASylated proteins [28]. A fusion of a 600-residue PAS polypeptide with a type I IFN, the product of which was called YNS $\alpha 8$, was demonstrated to possess both a tenfold longer half-life and pharmacodynamic activity in transgenic mice than IFN itself [123]. Arne Skerra (of Technische Universität München) founded a biotech company, XL-Protein GmbH (http://www.xl-protein.com), to commercialize the use of PASylation to improve the half-lives of peptides and small proteins [124]. Currently, XL-Protein $\mathrm{GmbH}$ has 15 preclinical programs listed on their website, six of which appear to be intended as extended-half-life biobetter forms of existing peptides and short protein products (Table 6).

\subsection{Other Polypeptide Fusion Approaches}

Another approach for utilizing polypeptide chains to extend the half-life of peptides or proteins is "HAPylation" (Table 2), e.g., use of a glycine-rich HAP genetic fusion to increase half-life [27]. Inert repeat sequences similar or identical to $\left(\mathrm{Gly}_{4} \mathrm{Ser}\right)_{n}$ have been used for many years as linker sequences to link subunits, single chains, and peptides together [125].

Schlapschy et al. [27] investigated the use of HAPylation to increase the hydrodynamic radius of an anti-HER2 Fab 4D5 to extend the Fab's half-life in animal models. They fused 100 and 200 residues of a repetitive sequence $\left(\mathrm{Gly}_{4} \mathrm{Ser}\right)_{n}$ to its light chain and showed that the 200 residue "HAPylated" Fab had a hydrodynamic volume more than double that of the Fab alone, resulting in a moderate increase in half-life. It does not appear that this technology has been developed further.

Finally, a gelatin-like protein (GLK) polymer was fused to G-CSF to generate a long-half-life derivative [51]. The GLK-G-CSF fusion protein retained the same activity as recombinant G-CSF on a molar basis, indicating that the fusion did not affect activity, as so often occurs with fusions and conjugates. Additionally, the half-life in rats was increased from $1.76 \mathrm{~h}$ (rG-CSF) to about $10 \mathrm{~h}$ (rGLKG-CSF), similar to the values obtained with Neulasta ${ }^{\circledR}$ (PEG conjugate; Table 1) and Albugranin ${ }^{\mathrm{TM}}$ (albumin fusion; Table 6).

\section{Comparison of the Various Fusion Protein Formats}

Table 7 shows a comparison of the various half-life-extension platforms described in this paper. The most widely used, best understood, and most "conservative" constructs are Fc fusion proteins. This platform was first described in the late 1980s [54], and in the form of etanercept (Enbrel $^{\circledR}$ ), it has been manufactured for human use since 1998 .
Fc fusion has become so common that it is widely used to generate reagent proteins for assays and experiments, and $\mathrm{Fc}$ fusions of receptor exodomains and other proteins are widely available commercially as test reagents. Additionally, ten $\mathrm{Fc}$ fusion proteins have now been approved in major markets for medical use (Table 4). This widespread knowledge has a potential downside from the patentability side (see Sect. 8.6), as it is usually now considered obvious to make an $\mathrm{Fc}$ fusion protein to lengthen the half-life of receptor exodomains and cytokines [125]. Of the other fusion protein partners, HSA fusion proteins have now been pretty well characterized [18] and are represented by one marketed product (Table 4) and at least another eight clinical candidates (Table 6). Additionally, the use of CTP as a fusion partner to extend the half-lives of proteins has been well characterized, with one marketed product (Table 4) and three more clinical candidates. Beyond those examples, however, the overall knowledge about fusion partners, such as ELP, XTEN, PAS, HAP, and others, becomes much thinner, and the safety, efficacy, potential immunogenicity, and manufacturing profiles of these lesser studied fusion proteins are more difficult to assess (Table 7). It does appear, however, that VRS-317 (XTENhGH) [119] and Glymera ${ }^{\text {TM }}$ (ELP-GLP-1) [75], both currently in phase 2 , may have properties (e.g., activity, efficacy, pharmacokinetics, lack of high immunogenicity) that are solid enough to take into late-stage development, which will more definitively test their characteristics as potential drugs. The other platforms (e.g., PASylation, HAPylation, GLK-fusion) are too early in development for us to know yet whether they can stand the test of clinical and scale-up manufacturing development.

\section{Potential Issues with Biobetter Fusion Proteins}

Fusion proteins made with Fc, HSA, CTP, XTEN, or other fusion partners described in this review are novel molecules not found in nature. They are instead constructed of two or more parts of proteins found in nature and are often fused together genetically via unnatural amino acid linkers. In some cases, the half-life-extension fusion partner is not natural, such as XTEN, HAP, GLK, PAS, or ELP, all of which utilize repeat units of amino acids. These types of unnatural proteins, even though they are constructed at least in part with natural components, can raise a series of potential manufacturing and dosing challenges, including developability, stability, solubility, immunogenicity, and loss of activity in comparison with the native protein. During development of these novel extended-half-life protein fusions, these and other factors need to be taken into careful consideration to reduce unwanted side effects or unstable products. 
Table 7 Comparison of the various fusion protein formats

\begin{tabular}{|c|c|c|c|c|c|}
\hline $\begin{array}{l}\text { Pharmacokinetic } \\
\text { extension format }\end{array}$ & $\begin{array}{l}\text { Date first } \\
\text { described } \\
\text { [references] }\end{array}$ & $\begin{array}{l}\text { Furthest } \\
\text { advance }\end{array}$ & Half-life potential & Immunogenicity potential & Potential issues \\
\hline Fc fusion & $1989[54]$ & $\begin{array}{l}\text { Approved for } \\
\text { commercial } \\
\text { use }\end{array}$ & $\begin{array}{l}\text { Proven; half-life range from } \\
4 \text { days (etanercept) to } \\
\sim 16 \text { days (abatacept) in } \\
\text { humans }\end{array}$ & $\begin{array}{l}\text { Modest in those Fc fusions } \\
\text { currently marketed; } \\
\text { potential for neo-epitopes } \\
\text { in linker fusion region }\end{array}$ & $\begin{array}{l}\text { Stability, aberrant } \\
\text { glycosylations in linkers and } \\
\text { fusion proteins; Fc } \\
\text { functionality or lack thereof }\end{array}$ \\
\hline HSA fusion & $1992[90]$ & $\begin{array}{l}\text { Approved for } \\
\text { commercial } \\
\text { use }\end{array}$ & $\begin{array}{l}\text { Proven; about } 5 \text { days in } \\
\text { humans }\end{array}$ & $\begin{array}{l}\text { Modest in those HSA fusions } \\
\text { currently marketed; } \\
\text { potential for neo-epitopes } \\
\text { in linker fusion region }\end{array}$ & $\begin{array}{l}\text { Biodistribution may be more } \\
\text { limited }\end{array}$ \\
\hline CTP fusion & $1992[34]$ & $\begin{array}{l}\text { Approved for } \\
\text { commercial } \\
\text { use }\end{array}$ & $\begin{array}{l}\text { Proven, albeit modest ( } \sim 3- \\
\text { day half-life is typical in } \\
\text { humans) }\end{array}$ & $\begin{array}{l}\text { Very low incidence }(0.16 \%) \\
\text { for Elonva }{ }^{\circledR} \text {; all positives } \\
\text { were non-neutralizing }\end{array}$ & $\begin{array}{l}\text { Modest half-life } \\
\text { improvement; strong } \\
\text { negative charge may impact } \\
\text { biological activity for some } \\
\text { fusions }\end{array}$ \\
\hline XTEN fusion & 2009 [17] & $\begin{array}{l}\text { Clinical } \\
\text { phase } 3\end{array}$ & $\begin{array}{l}\text { Proven; about } 4-5 \text { days in } \\
\text { humans [120] }\end{array}$ & $\begin{array}{l}\text { About } 10 \% \text { low-level, non- } \\
\text { neutralizing ADAs in VRS- } \\
317 \text { phase } 1 \text { study }\end{array}$ & Many unknowns \\
\hline ELPylation & $1992[126]$ & $\begin{array}{l}\text { Clinical } \\
\text { phase } 2\end{array}$ & $\begin{array}{l}\text { Approximately } 3 \text { days in } \\
\text { phase } 1 \text { study of } \\
\text { Glymera }^{\mathrm{TM}}\end{array}$ & $\begin{array}{l}<4 \% \text { in phase } 1 \text { study of } \\
\text { Glymera }{ }^{\mathrm{TM}} \text {; all were low- } \\
\text { level, non-neutralizing } \\
\text { ADAs }\end{array}$ & Many unknowns \\
\hline $\begin{array}{l}\text { Human } \\
\text { transferrin } \\
\text { fusion }\end{array}$ & 2004 [127] & Preclinical & Unknown for humans & Unknown & Many unknowns \\
\hline PASylation & $2008[128]$ & Preclinical & $\begin{array}{l}\text { Unknown for humans; } 2-3 \\
\text { days in mice, } \\
\text { approximately } 8 \text { - to } \\
\text { tenfold over native protein }\end{array}$ & $\begin{array}{l}\text { Unknown, but unlikely to be } \\
\text { due to simple repeating } \\
\text { sequence of PAS residues }\end{array}$ & Many unknowns \\
\hline HAPylation & 2007 [27] & Preclinical & $\begin{array}{l}\text { Unknown for humans; only } \\
\sim 6 \text {-h half-life in mice }\end{array}$ & Unknown for humans & $\begin{array}{l}\text { Seemingly short-half-life } \\
\text { improvement; many } \\
\text { unknowns }\end{array}$ \\
\hline GLK fusion & $2010[51]$ & Discovery & $\begin{array}{l}\text { Unknown for humans; about } \\
8-10 \mathrm{~h} \text { in rats, } \\
\text { approximately fivefold } \\
\text { increase over native } \\
\text { protein }\end{array}$ & $\begin{array}{l}\text { Unknown for humans; no } \\
\text { immunogenicity in mice } \\
\text { [51] }\end{array}$ & $\begin{array}{l}\text { Seemingly short-half-life } \\
\text { improvement; many } \\
\text { unknowns }\end{array}$ \\
\hline
\end{tabular}

$A D A$ anti-drug antibody, $C T P$ carboxy-terminal peptide, $E L P$ elastin-like peptide, $F c$ constant fragment, $G L K$ gelatin-like protein, $H A P$ homoamino acid polymer, HSA human serum albumin, $P A S$ proline-alanine-serine polymer, XTEN genetic fusion of non-exact repeat peptide sequence

\subsection{Half-Life Improvements}

The mean and median half-life values for approved therapeutic antibodies are about 12-13 days, about a week shy of the oft-quoted textbook values of approximately 21 days [53]. Nevertheless, most of the Fc fusion proteins generated to date have half-life values in humans of about 4-5 days (Table 7). The notable exception is abatacept, which has a half-life of about 13-16 days [129]. Belatacept, which has a structure that differs from abatacept by only two amino acid residues, has an average half-life of about 8-9 days [130]. The shorter-half-life values for Fc fusion proteins may be due to lower affinity to FcRn or the higher-order structure provided by Fab arms of normal antibodies [131]. Additionally, the protein or peptide "head groups" of Fc fusion proteins are likely the targets of proteinases that increase their turnover. Similarly, even though serum albumin has a half-life in humans of about 19 days, the half-life of albiglutide is only about 5 days. Thus far, other fusion partners tested in the clinic, such as CTP, ELP, or XTEN, have done no better, with the fusion proteins possessing half-life values of $2.5,4-5$, and 4-5 days, respectively (Table 7). Thus, with the possible exceptions of abatacept and the structurally related belatacept, the halflife values of fusion proteins are typically less than 5 days, which would be on the low side for a typical therapeutic 
monoclonal antibody [53]. For most of these fusion proteins, the best dosing schedule to be expected would be weekly, with some potentially requiring two doses per week. While this is far better than the native peptides or proteins alone, it is still far more frequent dosing than that of most therapeutic antibodies [53].

\subsection{Activity of Protein Fusions: Importance of Protein Engineering for Activity}

The in vitro biological activity of fusion proteins, as measured by the half-maximal inhibitory concentration $\left(\mathrm{IC}_{50}\right)$ or the half-maximal effective concentration $\left(\mathrm{EC}_{50}\right)$, is often lower than that of the original biologic that has been fused to a protein to elongate its pharmacokinetic profile [132-134]. These losses in activity may be due to the decrease in the on-rate due to the bulkiness of the fusion protein as compared with the original bioactive protein, or, alternatively, steric hindrance. It has been demonstrated that the linker type, length, and flexibility, as well as fusion of the bioactive peptide or protein to the $\mathrm{C}$ or $\mathrm{N}$ terminus of the half-life-extension module, can have profound effects on the activity of the fusion proteins. Examples follow for this phenomenon, and also for how protein engineering in some cases can overcome this loss of activity.

One example of this was demonstrated by Peng et al. [133], who compared the in vitro activity, pharmacokinetics, and in vivo activity on somatostatin receptors (SSTRs) 1-5 of native protein somatostatin-14 (SST14) with a somatostatin-14 fusion (two 14-amino-acid copies of SST14 fused to HSA; SST14 ${ }_{2}$-HSA). Fusion of HSA to somatostatin-14 resulted in a 2.5 -fold loss of activity for SSTR4 and an approximate 15-fold loss of activity for SSTR5, as measured by $\mathrm{EC}_{50}$ binding values for the various SSTRs [133]. Interestingly, the HSA fusion affected binding to the SSTRs differentially, resulting in different ratios, which could potentially result in modified in vivo functionality and/or toxicity profiles. Additionally, SST14 2 -HSA induced significantly lower levels of phosphorylation of the SSTR2 and SSTR3 downstream signaling enzyme, ERK1/2, than did native SST14 [133], as well as increasing the $\mathrm{EC}_{50}$ for cyclic adenosine monophosphate (cAMP) accumulation by more than a log. Finally, the HSA fusion inhibited SST receptor turnover as compared with that of native SST14 [133]. Peng et al. [133] did not try to engineer the linkers between the SST and HSA in attempts to try to improve activity, so it is unknown if the loss of activity might have been recovered with further protein engineering.

In another example, linker engineering was used to regain activity lost upon fusion of IFN- $\alpha_{2 b}$ to HSA [134]. A direct fusion of IFN- $\alpha_{2 b}$ to HSA resulted in an unstable protein with very little biological activity [134]. Zhao et al. tested the effects of different linkers on the activity of IFN$\alpha_{2 b}$ in a fusion format. Peptide linkers are known to have an influence on the expression, activity, and pharmacokinetics of fusion proteins [132, 135]. Peptide linkers typically come in either flexible forms (e.g., (G4S)n, where $n=1-4$ ) or in structurally more rigid forms, such as the $\alpha$ helical linker [A(EAAAK) $n \mathrm{~A}] x$ (where $n=2-4$ and $x=1$ or 2), and XPn (where $\mathrm{X}$ is either $\mathrm{A}, \mathrm{K}$ or $\mathrm{E})[132,135]$. The advantage of flexible linkers is that the flexibility may be required to obtain proper orientation of the bioactive portion of the molecule with respect to its cognate receptor, whereas flexible linkers do not give a lot of space between the fusion partner and the bioactive protein $[132,135]$. Rigid linkers, on the other hand, provide more space but lack the flexibility $[132,135]$. In the case of the IFN- $\alpha_{2 b}$ HSA fusion protein, the flexible linker resulted in approximately $39 \%$ activity as compared with that of native IFN- $\alpha_{2 b}$, whereas the rigid XP linker and the $\alpha$ helical linker resulted in 68 and $115 \%$ of the activity of native IFN- $\alpha_{2 b}$, respectively [134]. Additionally, the fusion proteins were demonstrated to possess good stability and solubility. In another example, G-CSF was fused to transferrin, using a variety of different linkers. The use of a short leucine-glutamate (LE) linker resulted in only approximately $10 \%$ of the activity of native G-CSF, whereas insertion of either a $(\mathrm{G} 4 \mathrm{~S}) 3$ or $\alpha$-helical $[\mathrm{A}(\mathrm{EAAAK}) n \mathrm{~A}] m(n=2-4, m=1$ or 2$)$ linker significantly increased the activity of the fusion proteins over that of G-CSF-LE-Tf. The fusion protein constructed with the linker (A(EAAAK)4ALEA-(EAAAK)4A) resulted in biological activity near to that of native G-CSF, with the added advantage of a long half-life in vivo [136]. These studies demonstrate the importance of testing linker technology for the success of fusion protein programs.

Using a different approach, Ding et al. [137] demonstrated the importance of fusion position for activity. The fused brain natriuretic peptide (BNP) to either the $\mathrm{N}$ or $\mathrm{C}$ terminus of HSA in several formats. The results showed that BNP-HSA, BNP2-HSA (two copies of BNP), and BNP4-HSA, all fused to the $\mathrm{N}$ terminus of HSA, were devoid of significant biological activity, whereas HSABNP2, fused to the C-terminus of HSA, was nearly as active as native BNP, plus it had the advantage of a significantly longer half-life [137].

These examples and many more like them in the literature demonstrate the importance of having a significant effort in lead optimization of fusion proteins to optimize the activity either through linker engineering, the position of the bioactive protein or peptide with respect to the halflife-extension module, or both. 


\subsection{Developability and Stability Issues}

One of the key issues facing the construction of novel molecules is the potential for aggregation, particularly at high concentrations, which are desired for formulations for subcutaneous delivery. During the development of the vascular endothelial growth factor (VEGF)-trap, which is now commercially available as Eylea ${ }^{\circledR}$ for treatment of age-related macular degeneration (AMD), and Zaltrap ${ }^{\circledR}$, which is available for treatment of metastatic colon cancer, the first construct, which consisted of the first three domains of VEGF receptor-1 (VEGFR1) fused to the human $\operatorname{IgG}_{1} \mathrm{Fc}$ region, was highly potent but had poor pharmacokinetics and possessed non-specific binding interactions, which made it unsuitable as a clinical candidate. Further engineering of the molecule was required to result in the clinical candidate, which possesses better pharmacokinetics, affinity, stability, and specificity [138].

Finally, aggregation, poor solubility, and lack of stability are key factors that can lead to heightened immunogenicity, which can lead to increased clearance of the drug, or, at worst, can generate an immune response that also binds and clears the native protein [53].

\subsection{Immunogenicity and Safety}

One of the most critical issues for any protein therapeutic is immunogenicity [139, 140]. Proteins contain both B cell and $\mathrm{T}$ cell epitopes, which can be recognized by the immune system as either self or foreign. B cell epitopes are conformational epitopes found on the surface of the proteins and are relatively difficult to assess preclinically. $\mathrm{T}$ cell epitopes, on the other hand, are small linear peptides, which are processed and presented by MHC to $\mathrm{T}$ cells. Because of the extensive structural/functional characterization of MHC-peptide complexes, many $\mathrm{T}$ cell epitopes are known or can be predicted. Several computer algorithms have been devised to test for the presence of human $\mathrm{T}$ cell epitopes in proteins. Since non-human animal models clearly are not predictive of immunogenicity in humans, the ability to test for immunogenicity preclinically is limited. For most therapeutic proteins, efforts are made to "de-immunize" the protein by eliminating as many $\mathrm{T}$ cell epitopes as possible, using in silico $\mathrm{T}$ cell epitope recognition programs and/or in vitro $\mathrm{T}$ cell assays [139]. Additionally, it has been suggested that addition of regulatory T cell epitopes, called "Tregitopes", may decrease the immunogenicity of the fusion protein [139].

For most antibodies, significant immunogenicity results in elimination of the antibody from the serum, so the most significant issue is one of efficacy or lack thereof [53]. That said, the incidence of immunogenicity for most humanized and human antibodies is quite low, e.g., less than $10 \%$, with most anti-drug responses being non-neutralizing [53]. For therapeutic proteins or fusion proteins containing a native protein domain, however, immunogenicity of the therapeutic product could potentially result in an immune response against the native protein, which could potentially exacerbate the disease for which the patient is being treated [141]. Immunogenicity of fusion proteins may arise from the fusion sites (which may form neo-epitopes not recognized as self by the immune system), from allotypic responses to proteins containing allogeneic sequences, by improper formulation or packaging (which might lead to the presence of an adjuvant that helps to drive an immune response against the delivered protein [141]), or from aggregation of the product (which could help drive the immune response). Thus, optimization of the primary sequence to reduce B or T cell epitopes [139] is only part of the equation. Formulation, chemical and structural stability, lack of aggregation, solubility, and route of administration are also key factors to consider to minimize immunogenicity of fusion proteins [53, 139, 140].

Thus far, Fc fusion proteins have been shown to have an overall low incidence of immunogenicity as reported in the package inserts for the products: etanercept has an incidence of about $6 \%$, with the anti-drug response generally being non-neutralizing [142]; fewer than $2 \%$ of patients treated with abatacept developed antibodies against the drug, and while some of these were found to be neutralizing, there appeared to be little effect on clearance [129]; for belatacept, which is a modified version of abatacept, about $8 \%$ of patients generated an anti-drug response, but clearance was not substantially affected [130]; about $1.6 \%$ of patients treated with dulaglutide generated anti-drug antibodies, and about half of those were found to be neutralizing. The one Fc fusion protein for which high antidrug antibody titers were reported was rilonacept, to which $35 \%$ of patients who were tested generated an anti-drug response [143]. It was reported, however, that these responses were not associated with exaggerated clearance or loss of activity of the drug.

For other types of fusion proteins, only low incidence rates of anti-drug responses have been reported thus far. For example, for the CTP fusion protein Elonva ${ }^{\circledR}$, fewer than $0.2 \%$ of patients generated anti-drug responses; for the ELP fusion protein Glymera $^{\mathrm{TM}}$, less than $4 \%$ immunogenicity was observed, and for the HSA fusion protein Tanzeum ${ }^{\circledR}$, about $5 \%$ of patients generated nonneutralizing low-level anti-drug antibodies, which were not correlated with clearance or loss of activity.

While these data are promising thus far, the potential for immunogenicity that could result in antibodies against the native proteins of protein fusions is still an important consideration, which must be followed very carefully during the development of these kinds of drugs. One word 
of caution in all of these reports is that the immunogenicity assays used across the industry vary widely with respect to sensitivity and specificity, so it is difficult to compare data accurately across drugs or platforms [139].

\subsection{Ancillary Activities}

In generating $\mathrm{Fc}$ fusions, the activity of the $\mathrm{Fc}$, which can bind to Fc $\gamma$ receptors on several types of immune cells, needs to be taken into consideration [53, 140, 144]. This has been handled in different ways. For etanercept, the $\mathrm{IgG}_{1} \mathrm{Fc}$ was left intact but, because of the structure, this resulted in overall lesser $\mathrm{Fc}$ functionality than what is observed with an $\mathrm{IgG}_{1}$ antibody [145]. It has been postulated that this lowered Fc activity may have resulted in poorer efficacy in intestinal bowel diseases, where the Fc activity may be important for binding cell surface-associated TNF- $\alpha$ [145]. For abatacept, the Fc and hinge region were modified to reduce effector function [146].

\subsection{Obviousness}

One of the major problems today with the use of fusion proteins such as Fc, IgG, or albumin to generate a biobetter by extending the half-life of a biologically active, commercially available peptide or protein (e.g., G-CSF, hGH, etc.) is that it is now an obvious approach to take. This obviousness has made it much more difficult to obtain patent protection for constructs of these types [125]. There are some examples in which obviousness may be obviated, i.e., if the bioactive protein has been modified to possess new or different activities from the original, or if making a dimer using Fc or both ends of HSA significantly increases activity or changes the biodistribution in a way that confers novel biology or efficacy.

\section{Summary}

It is clear that biobetter drugs are here to stay. This review has documented six marketed biobetter drugs generated via protein fusion technologies, four of which (Alprolix ${ }^{\circledR}$, Tanzeum ${ }^{\circledR}$, Eloctate ${ }^{\circledR}$, Trulicity ${ }^{\circledR}$ ) were approved for marketing in just the past year (2014). Another 15 biobetter clinical-stage candidate drugs and 23 preclinical-stage candidates generated by protein fusion technologies have also been discussed. The technologies most used thus far have been albumin fusion and Fc fusion technologies, with XTEN fusion, ELP fusion, and CTP fusion technologies making significant advances over the past few years. Within a few years, XTEN and ELP will likely join HSA, Fc, and CTP as fusion partners represented by a marketed biobetter drug. This, along with other biobetter fusion proteins reaching approval in the next few years, will give us a better view of which half-life-extension fusion technologies are best suited for which purposes (e.g., peptide versus protein fusions).

\section{Compliance with Ethical Standards}

Conflicts of interest The author is an employee of Janssen R\&D, Pharmaceutical Companies of Johnson \& Johnson. He received no funding for this manuscript above and beyond his salary, and no Johnson \& Johnson drugs are mentioned in this paper.

Open Access This article is distributed under the terms of the Creative Commons Attribution-NonCommercial 4.0 International License (http://creativecommons.org/licenses/by-nc/4.0/), which permits any noncommercial use, distribution, and reproduction in any medium, provided you give appropriate credit to the original author(s) and the source, provide a link to the Creative Commons license, and indicate if changes were made.

\section{References}

1. Caliceti P, Veronese FM. Pharmacokinetic and biodistribution properties of poly(ethylene glycol)-protein conjugates. Adv Drug Delivery Rev. 2003;55:1261-77.

2. Jevševar S, Kunstelj M, Porekar VG. PEGylation of therapeutic proteins. Biotechnol J. 2010;5:113-28.

3. Werle M, Bernkop-Schnurch A. Strategies to improve plasma half life time of peptide and protein drugs. Amino Acids. 2006;30:351-67.

4. Holst JJ. The physiology of glucagon-like peptide 1. Physiol Rev. 2007;87:1409-39.

5. Diao L, Meibohm B. Pharmacokinetics and pharmacokineticpharmacodynamic correlations of therapeutic peptides. Clin Pharmacokinet. 2013;52:855-68.

6. Supersaxo A, Hein WR, Steffan H. Effect of molecular weight on the lymphatic absorption of water-soluble compounds following subcutaneous administration. Pharm Res. 1990;7:167-9.

7. Tang L, Persky AM, Hochhaus G, et al. Pharmacokinetic aspects of biotechnology products. J Pharm Sci. 2004;93:2184-204.

8. Andersen JT, Pehrson R, Tolmachev V, et al. Extending half-life by indirect targeting of the neonatal $\mathrm{Fc}$ receptor $(\mathrm{FcRn})$ using a minimal albumin binding domain. J Biol Chem. 2011;286:5234-41.

9. O'Connor-Semmes RL, Lin J, Hodge RJ, et al. GSK2374697, a novel albumin-binding domain antibody (albudAb), extends systemic exposure of extendin-4: first study in humans-PK/PD and safety. Clin Pharmacol Ther. 2014;96:704-12.

10. Sockolosky JT, Kivimae S, Szoka FC. Fusion of a short peptide that binds immunoglobulin $G$ to a recombinant protein substantially increases its plasma half-life in mice. PLoS One. 2014;9:e102566.

11. Kontermann RE. Strategies to extend plasma half-lives of recombinant antibodies. BioDrugs. 2009;23:93-109.

12. Kang JS, DeLuca PP, Lee KC. Emerging PEGylated drugs. Expert Opin Emerg Drugs. 2009;14:363-80.

13. Pasut G, Veronese FM. Second-generation pharmaceutical proteins-EUFEPS workshop on optimizing biotech medicines. IDrugs. 2007;10:162-4.

14. Bendele A, Seely J, Richey C, et al. Short communication: renal tubular vacuolation in animals treated with polyethylene-glycolconjugated proteins. Toxicol Sci. 1998;42:152-7.

15. Fee CJ, Van Alstine JN. Purification of pegylated proteins. In: Janson J-C, editor. Protein purification: principles, high 
resolution methods, and applications. 3rd ed. New York: Wiley; 2011. p. 339-62.

16. MacDougall IC, Gray SJ, Elston O, et al. Pharmacokinetics of novel erythropoiesis stimulating protein compared with epoetin alfa in dialysis patients. J Am Soc Nephrol. 1999;10:2392-5.

17. Schellenberger V, Wang CW, Geething NC, et al. A recombinant polypeptide extends the in vivo half-life of peptides and proteins in a tunable manner. Nat Biotechnol. 2009;27:1186-90.

18. Somers G. Structural aspects of fusion proteins determining the level of commercial success. In: Schmidt S, editor. Fusion protein technologies for biopharmaceuticals: applications and challenges. Hoboken: Wiley; 2013. p. 87-121.

19. Beck A. Biosimilar, biobetter and next generation therapeutic antibodies. MAbs 2011;3:107-110.

20. Lan $\mathrm{H}, \mathrm{Li}$ W, Fu Z, et al. Differential intracellular signaling properties of the growth hormone receptor induced by the activation of an anti-GHR antibody. Mol Cell Endrocrinol. 2014:390:54-64.

21. Beck A, Reichert, JM. Therapeutic Fc-fusion proteins and peptides as successful alternatives to antibodies. MAbs. 2011;3:1-2.

22. Czajkowsky DM, Hu J, Shao Z, et al. Fc-fusion proteins: new developments and future perspectives. EMBO Mol Med. 2012;4:1015-28.

23. Huang C. Receptor-Fc fusion therapeutics, traps, and Mimetibody $^{\text {TM }}$ technology. Curr Opin Biotechnol. 2009;20:692-9.

24. Keefe D, Heartlein M, Josiah S. Transferrin fusion protein therapies: acetylcholine receptor-transferrin fusion protein as a model. In: Schmidt S, editor. Fusion protein technologies for biopharmaceuticals: applications and challenges. Hoboken: Wiley; 2013. p. 345-56.

25. Weimer T, Metzner HJ, Schulte S. Recombinant albumin fusion proteins. In: Schmidt S, editor. Fusion protein technologies for biopharmaceuticals: applications and challenges. Hoboken: Wiley; 2013. p. 297-323.

26. Walker A, Dunlevy G, Topley P. Albumin-binding fusion proteins in the development of novel long-acting therapeutics. In: Schmidt S, editor. Fusion protein technologies for biopharmaceuticals: applications and challenges. Hoboken: Wiley; 2013. p. $325-43$.

27. Schlapschy M, Theobald I, Mack H, et al. Fusion of a recombinant antibody fragment with a homo-amino-acid polymer: effects on biophysical properties and prolonged plasma half-life. Protein Eng Des Sel. 2007;20:273-84.

28. Schlapschy M, Binder U, Borger C, et al. PASylation: a biological alternative to PEGylation for extending the plasma halflife of pharmaceutically active proteins. Protein Eng Des Sel. 2013;26:489-501.

29. Floss DM, Schallau K, Rose-John S, et al. Elastin-like polypeptides revolutionize recombinant protein expression and their biomedical application. Trends Biotechnol. 2010;28:37-45.

30. Floss DM, Conrad U, Rose-John S, et al. ELP-fusion technology for biopharmaceuticals. In: Schmidt S, editor. Fusion protein technologies for biopharmaceuticals: applications and challenges. Hoboken: Wiley; 2013. p. 372-98.

31. Mero A, Pasqualin M, Campisi M, et al. Conjugation of hyaluronan to proteins. Carb Polymers. 2013;92:2163-70.

32. Gregoriadis G, Jain S, Papaioannou I, et al. Improving the therapeutic efficacy of peptides and proteins: a role for polysialic acids. Int J Pharm. 2005;300:125-30.

33. Duijkers IJ, Klipping C, Boerrigter PJ, et al. Single dose pharmacokinetics and effects on follicular growth and serum hormones of a long-acting recombinant FSH preparation (FSHCTP) in healthy pituitary-suppressed females. Hum Reprod. 2002;17:1987-93.
34. Fares FA, Suganuma N, Nishimori K, et al. Design of a longacting follitropin agonist by fusing the C-terminal sequence of the chorionic gonadotropin beta subunit to the follitropin beta subunit. Proc Natl Acad Sci USA. 1992;89:4304-8.

35 . Fares F. Half-life extension through $O$-glycosylation. In: Schmidt $\mathrm{S}$, editor. Fusion protein technologies for biopharmaceuticals: applications and challenges. Hoboken: Wiley; 2013. p. $358-71$.

36. Doppalapudi VR, Tryder N, Li L, et al. Chemically programmed antibodies: endothelin receptor targeting CovX-bodies. Bioorg Med Chem Lett. 2007;17:501-6.

37. Bhat A, Laurent O, Lappe R. CovX-bodies. In: Schmidt S, editor. Fusion protein technologies for biopharmaceuticals: applications and challenges. Hoboken: Wiley; 2013. p. 956-70.

38. Gow DJ, Sauter KA, Pridans, et al. Characterisation of a novel $\mathrm{Fc}$ conjugate of macrophage colony-stimulating factor. Mol Ther. 2014;22:1580-92.

39. Smith BJ, Popplewell A, Athwal D, et al. Prolonged in vivo residence times of antibody fragments associated with albumin. Bioconjug Chem. 2001;12:750-6.

40. Schmidt SR. Fusion proteins for half-life extension. In: Schmidt $\mathrm{S}$, editor. Fusion protein technologies for biopharmaceuticals: applications and challenges. Hoboken: Wiley; 2013. p. 178-201.

41. Yousefpour P, Chilkoti A. Co-opting biology to deliver drugs. Biotechnol Bioeng. 2014;111:1699-716.

42. Mannucci PM. Half-life extension technologies for haemostatic agents. Thromb Haemost. 2015;113:165-76.

43. Ghetie V, Ward ES. Transcytosis and catabolism of antibody. Immunol Res. 2002;25:97-113.

44. Roopenian DC, Akilesh S. FcRn: the neonatal Fc receptor comes of age. Nature Rev Immunol. 2007;7:715-25.

45. Baker K, Qiao S-W, Kuo T, et al. Immune and non-immune functions of the (not so) neonatal Fc receptor, FcRn. Semin Immunopathol. 2009;31:223-6.

46. Giragossian C, Clark T, Piche-Nicholas N, et al. Neonatal Fc receptor and its role in the absorption, distribution, metabolism and excretion of immunoglobulin G-based biotherapeutics. Curr Drug Metab. 2013;14:764-90.

47. Chaudhury C, Mehnaz S, Robinson JM, et al. The major histocompatability complex-related $\mathrm{Fc}$ receptor for $\mathrm{IgG}(\mathrm{FcRn})$ binds albumin and prolongs its lifespan. J Exp Med. 2003; $197: 315-22$.

48. Chaudhury C, Brooks CL, Carter DC, et al. Albumin binding to FcRn: distinct from the FcRn-IgG interaction. Biochemistry. 2006;45:4983-90.

49. Chen X, Lee H-F, Zaro JL, et al. Effects of receptor binding on plasma half-life of bifunctional transferrin fusion proteins. Mol Pharm. 2011;8:457-65.

50. Conrad U, Plagmann I, Malchow S, et al. ELPylated anti-human TNF therapeutic single-domain antibodies for prevention of lethal septic shock. Plant Biotechnol. 2011;9:22-31.

51. Huang Y-S, Wen X-F, Wu Y-L, et al. Engineering a pharmacologically superior form of granulocyte-colony-stimulating factor by fusion with gelatin-like protein polymer. Eur J Pharm Biopharm. 2010;72:435-41.

52. Kim J-K, Firan M, Radu CG, et al. Mapping the site on human $\mathrm{IgG}$ for binding of the MHC class I-related receptor, FcRn. Eur J Immunol. 1999;29:2819-25.

53. Strohl WR, Strohl LM. Therapeutic antibody engineering: current and future advances driving the strongest growth area in the pharma industry. Cambridge: Woodhead Publishing Series in Biomedicine No. 11; 2012.

54. Capon DJ, Chamow SM, Mordenti J, et al. Designing CD4 immunoadhesins for AIDS therapy. Nature. 1989;337:525-31.

55. Huang C, Swanson RV. Peptide-Fc fusion therapeutics: applications and challenges. In: Schmidt S, editor. Fusion protein 
technologies for biopharmaceuticals: applications and challenges. Hoboken: Wiley; 2013. p. 227-59.

56. Shimamoto G, Gegg C, Boone T, et al. Peptibodies: a flexible alternative format to antibodies. mAbs 2012;4:586-591.

57. Schmidt SR. Fusion protein technologies for biopharmaceuticals: applications and challenges. Hoboken: Wiley; 2013.

58. Dumont JA, Low S, Peters RT. Monomeric Fc fusions, impact on pharmacokinetic and biological activity of protein therapeutics. Biodrugs. 2006;20:151-60.

59. Mei B, Low SC, Krassova S, et al. Monomeric Fc-fusion proteins. In: Schmidt S, editor. Fusion protein technologies for biopharmaceuticals: applications and challenges. Hoboken: Wiley; 2013. p. 202-26.

60. Shapiro AD, Ragni MV, Valentino LA, et al. Recombinant factor IX-Fc fusion protein $(\mathrm{rFIX}-\mathrm{Fc})$ demonstrates safety and prolonged activity in a phase $1 / 2 \mathrm{a}$ study in hemophilia $\mathrm{B}$ patients. Blood. 2012;119:666-72.

61. Powell JS, Pasi KJ, Ragni MV, et al. Phase 3 study of recombinant factor IX Fc fusion protein in hemophilia B. N Engl J Med. 2013;369:2313-23.

62. Santagostino E, Negrier C, Klamroth R, et al. Safety and pharmacokinetics of a novel recombinant fusion protein linking coagulation factor IX with albumin (rIX-FP) in hemophila B patients. Blood. 2012;120:2405-11.

63. Carcao M. Changing paradigm of prophylaxis with longer acting factor concentrates. Haemophilia. 2014;20(Suppl 4):99-105.

64. Powell JS, Josephson NC, Quon D, et al. Safety and prolonged activity of recombinant factor VIII Fc fusion in hemophilia A patients. Blood. 2012;119:3031-7.

65. Lorenz M, Evers A, Wagner M. Recent progress and future options in the development of GLP-1 receptor agonists for the treatment of diabesity. Bioorg Med Chem Lett. 2013;23:4011-8.

66. Murphy KG, Dhillo WS, Bloom SR. Gut peptides in the regulation of food intake and energy homeostasis. Endocr Rev. 2006;27:719-27.

67. Eng J, Kleinman WA, Singh L, et al. Isolation and characterization of exendin-4, an exendin-3 analogue, from Heloderma suspectum venum: further evidence for an exendin receptor on dispersed acini from guinea pig pancreas. J Biol Chem. 1992;267:7402-5.

68. Glaesner W, Vick AM, Millican R, et al. Engineering and characterization of the long-acting glucagon-like peptide-1 anaglogue LY2189265, an Fc fusion protein. Diabetes Metab Res Rev. 2010;26:287-96.

69. Trulicity ${ }^{\circledR}$ (dulaglutide) prescribing information. Eli Lilly. 2014. http://pi.lilly.com/us/trulicity-uspi.pdf. Accessed 18 Feb 2015.

70. Tanzeum ${ }^{\circledR}$ (albiglutide) prescribing information. GlaxoSmith Kline LLC. 2014. https://www.gsksource.com/gskprm/htdocs/ documents/TANZEUM-PI-MG-IFU-COMBINED.PDF. Accessed 18 Feb 2015.

71. Victoza ${ }^{\circledR}$ (liraglutide) prescribing information. Novo Nordisk A/S. 2013. http://www.novo-pi.com/victoza.pdf. Accessed 18 Feb 2015.

72. Byetta ${ }^{\circledR}$ (exenatide) prescribing information. AstraZeneca Pharmaceuticals LP. 2014. http://www.azpicentral.com/byetta/ pi_byetta.pdf\#page=1. Accessed 18 Feb 2015 .

73. Bydureon ${ }^{\circledR}$ (exenatide extended release for injectable suspension) prescribing information. AstraZeneca Pharmaceuticals LP. 2014. http://www.azpicentral.com/bydureon/pi_bydureon.pdf\# page $=1$. Accessed 18 Feb 2015 .

74. Lyxumia ${ }^{\circledR}$ : EMA summary of product characteristics. Sanofi. 2013;1-92. http://www.ema.europa.eu/docs/en_GB/document_ library/EPAR_-_Product_Information/human/002445/WC50014 0401.pdf Accessed 18 Feb 2015.

75. Christiansen M, Matson M, Brazg R, et al. Weekly subcutaneous doses of Glymera (PB1023), a novel GLP-1 analogue reduces glucose exposure dose dependently. Amer Diabetes Aassoc Abstr. 2013;946P.

76. Bugelski PJ, Capocasale RJ, Makropoulos D, et al. CNTO 530: molecular pharmacology in human UT-7EPO cells and pharmacokinetics in mice. J Biotechnol. 2008;134:171-80.

77. Wang Q, Chen K, Liu R, et al. Novel GLP-1 fusion chimera as potent long acting GLP-1 receptor agonist. PLoS One. 2010;5:e12734.

78. Tezel TH, Bodek E, Sonmez K, et al. Targeting tissue factor for immunotherapy of choroidal neovascularization by intravitreal delivery of factor VII-Fc chimeric antibody. Ocul Immunol Inflam. 2007;15:3-10.

79. Yee A, Gildersleeve RD, Gu S, et al. A von Willebrand factor fragment containing the $\mathrm{D}^{\prime} \mathrm{D} 3$ domains is sufficient to stabilize coagulation factor VIII in mice. Blood. 2014;124:445-52.

80. Zollner S, Schuermann D, Raquet E, et al. Pharmacological characteristics of a novel, recombinant fusion protein linking coagulation factor VIIa with albumin (rVIIa-FP). J Thromb Haemost. 2014;12:220-8.

81. Halpern W, Riccobene TA, Agostini H, et al. Albugranin, a recombinant human granulocyte cology stimulating factor (GCSF) genetically fused to recombinant human albumin induces prolonged myelopoeitic effects in mice and monkeys. Pharm Res. 2002;19:1720-9.

82. Geething NC, To W, Spink BJ, et al. Gcg-XTEN: an improved glucagon capable of preventing hypoglycemia without increasing baseline blood glucose. PLoS One. 2010;5:e10175.

83. Alters SE, McLaughlin B, Spink B, et al. GLP2-2G-XTEN: a pharmaceutical protein with improved serum half-life and efficacy in a rat Crohn's disease model. PLoS One. 2013;7:e50630.

84. Lee CK, Yang S, Kang J, et al. Interferon-alpha (IFN-alpha) fused protein having IFN-alpha and a cytoplasmic transduction peptide. US Patent 2012:US20120134961 A1.

85. Choi J, Diao H, Feng Z-C, et al. A fusion protein derived from plants holds promising potential as a new oral therapy for type 2 diabetes. Plant Biotechnol J. 2014;12:425-35.

86. Kim B-J, Zhou J, Martin B, et al. Transferrin fusion technology: a novel approach to prolonging biological half-life of insulinotropic peptides. J Pharmacol Exp Ther. 2010;334:682-92.

87. Wang Y, Shao J, Zaro J, et al. Proinsulin-transferrin fusion protein as a novel long-acting insulin analog for the inhibition of hepatic glucose production. Diabetes. 2014;63:1779-88.

88. Kim Y-M, Lee SM, Chung H-S. Novel AGLP-1 albumin fusion protein as a long-lasting agent for type 2 diabetes. BMP Rep. 2013;46:606-10.

89. Kratz F. Albumin as a drug carrier: design of prodrugs, drug conjugates and nanoparticles. J Control Release. 2008;132:171-83.

90. Yeh P, Landais D, Lemaitre M, et al. Design of yeast-secreted albumin derivatives for human therapy: biological and antiviral properties of a serum albumin-CD4 genetic conjugate. Proc Natl Acad Sci USA. 1992;89:1904-8.

91. Hollon T. HGS targets patent-expiring drugs. Nature Biotechnol. 2000;18:1238-9.

92. Schulte S. Half-life extension through albumin fusion technologies. Thromb Res. 2009;124(Suppl 2):S6-8.

93. Schulte S. Innovative coagulation factors: albumin fusion technology and recombinant single-chain factor VIII. Thromb Res. 2013;131(Suppl 2):S2-6.

94. Fanali G, di Masi A, Trezza V, et al. Human serum albumin: from bench to bedside. Mol Aspects Med. 2012;33:209-90.

95. Sleep D, Cameron J, Evans LR. Albumin as a versatile platform for drug half-life extension. Biochim Biophys Acta. 2013;1830:5526-34.

96. Metzner HJ, Pipe SW, Weimer T, et al. Extending the pharmacokinetic half-life of coagulation factors by fusion to recombinant albumin. Thromb Haemost. 2013;110:931-9. 
97. Nolte MW, Nichols TC, Mueller-Cohrs J, et al. Improved kinetics of rIX-FP, a recombinant fusion protein linking factor IX with albumin, in cynomolgus monkey and hemophilia B dogs. J Thromb Haemost. 2012;10:1591-9.

98. Osborn BL, Sekut L, Corcoran M, et al. Albutropin: a growth hormone-albumin fusion with improved pharmacokinetics and pharmacodynamics in rats and monkeys. Eur $\mathrm{J}$ Pharmacol. 2002;456:149-58.

99. Subramanian GM, Fischella M, Lamouse-Smith A, et al. Albinterferon $\alpha-2 b$ : a genetic fusion protein for the treatment of chronic hepatitis C. Nature Biotechnol. 2007;25:1411-9.

100. Nelson DR, Benhamou Y, Chuang W-L, et al. Albinterferon alfa- $2 b$ was not inferior to pegylated interferon- $\alpha$ in a randomized trial of patients with chronic hepatitis $\mathrm{C}$ virus genotype 2 or 3. Gastroenterol. 2010;139:1267-76.

101. Richards DA, Braiteh FS, Garcia AA, et al. A phase 1 study of MM-111, a bispecific HER2/HER3 antibody fusion protein, combined with multiple treatment regimens in patients with advanced HER-positive solid tumors. J Clin Oncol. 2014;32(15 Suppl):651.

102. McDonagh C, Huhalov A, Harms BD, et al. Antitumor activity of a novel bispecific antibody that targets the ErbB2/ErbB3 oncogenic unit and inhabits hergulin-induced activation of ErbB3. Mol Cancer Ther. 2012;11:582-93.

103. Andersen JT, Dalhus B, Viuff D, et al. Extending serum half-life of albumin by engineering neonatal $\mathrm{Fc}$ receptor $(\mathrm{FcRn})$ binding. J Biol Chem. 2014;289:13492-502.

104. Wally J, Halbrooks PJ, Vonrhein C, et al. The crystal structure of iron-free serum transferrin provides insight into inter-lobe communication and receptor binding. $\mathrm{J}$ Biol Chem. 2006;281:24934-44.

105. Hsu VW, Bai M, Li J. Getting active: protein sorting in endocytic recycling. Nat Rev Mol Cell Biol. 2012;13:323-8.

106. Prior CP. Modified transferrin fusion proteins. 2007; US patent 7,176,278 B2.

107. Bai Y, Ann DK, Shen W-C. Recombinant granulocyte colonystimulating factor-transferrin fusion protein as an oral myelopoietic agent. Proc Natl Acad Sci USA. 2005;20:7292-6.

108. Matsubara M, Kanemoto S, Leshnower BG, et al. Single dose GLP-1-Tf ameliorates myocardial ischemia/reperfusion Injury. J Surg Res. 2009;165:38-45.

109. Wang Y, Chen Y-S, Zaro J, et al. Receptor-mediated activation of a proinsulin-transferrin fusion protein in hepatoma cells. J Control Release. 2011;155:386-92.

110. Matzuk MM, Hsueh AJ, Lapolt P, et al. The biological role of the carboxyl-terminal extension of human chorionic gonadotropin beta-subunit. Endocrinol. 1990;126:376-83.

111. Birken S, Canfield RE. Isolation and amino acid sequence of COOH-terminal fragments from the beta subunit of human choriogonadotropin. J Biol Chem. 1977;252:5386-92.

112. Fares F, Ganem S, Hajouj T, et al. Development of long-acting erythropoietin by fusing the carboxy-terminal peptide of human chorionic gonadotropin beta-subunit to the coding sequence of human erythropoietin. Endocrinology. 2007;148:5081-7.

113. Klein J, Lobel L, Pollak S, et al. Pharmacokinetics and pharmacodynamics of single-chain recombinant human folliclestimulating hormone containing the human chorionic gonadotropin carboxyterminal peptide in the rhesus monkey. Fertil Steril. 2002;77:1248-55.

114. Croxtall JD, McKeage K. Corifollitropin alfa: a review of its use in controlled ovarian stimulation for assisted reproduction. Biodrugs. 2011;25:243-54.

115. Fares F, Guy R, Bar-Ilan A, et al. Designing a long-acting human growth hormone (hGH) by fusing the carboxyl-terminal peptide of human chorionic gonadotropin (beta)-subunit to the coding sequence of hGH. Endocrinology. 2010;151:4410-7.
116. Zadik Z, Rosenfeld R, Radziuk K, et al. Top line results of onceweekly, CTP-modifed human GH (MOD-4023): phase 2 dose finding study in children with GH deficiency. Horm Res Pediatr. 2014;82(Suppl. 1):63.

117. Webster R, Xie R, Didier E, et al. PEGylation of somatropin (recombinant human growth hormone): impact on its clearance in humans. Xenobiotica. 2008;38:1340-51.

118. Tang Y-Y, Tang Z-H, Zhang Y, et al. The fusion protein of CTPHBcAg18-27-tapasin mediates the apoptosis of CD8+ $\mathrm{T}$ cells and CD8 $+\mathrm{T}$ cell response in HLA-A2 transgenic mice. Hepta Mon. 2014;14:e16161.

119. Cleland JL, Geething NC, Moore JA, et al. A novel long-acting human growth hormone fusion protein, (VRS-317): enhanced in vivo potency and half-life. J Pharm Sci. 2012;101:2744-54.

120. Yuen KCJ, Conway GS, Popovic V, et al. A long-acting human growth hormone with delayed clearance (VRS-317): results of a double-blind, placebo-controlled, single ascending dose study in growth hormone-deficient adults. J Clin Endrocrin Metab. 2013;98:2595-603.

121. Kimchi-Sarfaty C, Schiller T, Hamasaki-Katagiri N, et al. Building better drugs: developing and regulating engineered therapeutic proteins. Trends Pharmacol Sci. 2013;34:534-48.

122. Ago Y, Condro MC, Tan Y-V, et al. Reductions in synaptic proteins and selective alteration of prepulse inhibition in male C57BL/6 mice after postnatal administration of a VIP receptor (VIPR2) agonist. Psychopharmacol. 2015;232(12):2181-9.

123. Harari D, Kuhn N, Abramovich R, et al. Enhanced in vivo efficacy of a type I interferon superagonist with extended plasma half-life in a mouse model of multiple sclerosis. J Biol Chem. 2014;289:29014-29.

124. Skerra A. Extending plasma half-life of biologicals. EuroBiotechNews. 2009;8:34-7.

125. Schmidt SR. Fusion proteins: applications and challenges. In: Schmidt $\mathrm{S}$, editor. Fusion protein technologies for biopharmaceuticals: applications and challenges. Hoboken: Wiley; 2013. p. 19-59.

126. McPherson DT, Morrow C, Minehan DS, et al. Production and purification of a recombinant elastomeric polypeptide, G(VPGVG)19-VPGV, from Escherichia coli. Biotechnol Prog. 1992;8:347-52.

127. Prior CP, Lai C-H, Sadeghi $\mathrm{H}$ et al. Modified transferrin fusion proteins. Patent WO 2004/020405. 2004.

128. Skerra A, Theobald I, Schlapsky M. Biological active proteins having increased in vivo and/or vitro stability. Patent WO 2008/155134 A1. 2008.

129. Orencia ${ }^{\circledR}$ (abatacept) prescribing information. Bristol-Meyers Squibb. 2015. http://packageinserts.bms.com/pi/pi_orencia.pdf. Accessed 7 Jun 2015.

130. Nulojix ${ }^{\circledR}$ (belatacept) prescribing information. Bristol-Myers Squibb. 2014. http://packageinserts.bms.com/pi/pi_nulojix.pdf. Accessed 7 Jun 2015.

131. Suzuki T, Ishii-Watabe A, Tada M, et al. Importance of neonatal $\mathrm{FcR}$ in regulating the serum half-life of therapeutic proteins containing the $\mathrm{Fc}$ domain of human $\mathrm{IgG}_{1}$ : a comparative study of the affinity of monoclonal antibodies and $\mathrm{Fc}$-fusion proteins to human neonatal FcR. J Immunol. 2010;184:1968-76.

132. Chen X, Zaro J, Shen A-C. Fusion protein linkers: effects on production, bioactivity, and pharmacokinetics. In: Schmidt S, editor. Fusion protein technologies for biopharmaceuticals: applications and challenges. Hoboken: Wiley; 2013. p. 122-49.

133. Peng Y, Deng L, Ding Y, et al. Comparative study of somatostatin-human serum albumin fusion proteins and natural somatostatin on receptor binding, internalization and activation. PLoS One. 2014; 9:e89932.

134. Zhao HL, Yao XQ, Xue C, et al. Increasing the homogeneity, stability and activity of human serum albumin and interferon$\alpha 2 b$ protein by linke engineering. Prot Exp Purif. 2008;61:73-7. 
135. Chen X, Zaro J, Shen W-C. Fusion protein linkers: property, design and functionality. Adv Drug Deliv Rev. 2013;65:1357-69.

136. Bai Y, Shen W-C. Improving the oral efficacy of recombinant granulocyte colony-stimulating factor and transferrin fusion protein by spacer optimization. Pharm Res. 2006;23:2116-21.

137. Ding Y, Peng Y, Deng L, et al. The effects of fusion structure on the expression and bioactivity of human brain natriurectic peptide (BNP) albumin fusion proteins. Curr Pharmaceut Biotechnol. 2014;15:856-63.

138. Holash J, Davis S, Papadopoulos N, et al. VEGF-trap: a VEGF blocker with potent antitumor effects. Proc Natl Acad Sci USA. 2002;99:11393-8.

139. Jawa V, Cousens L, De Groote AS. Immunogenicity of therapeutic fusion proteins: contributory factors and clinical experience. In: Schmidt S, editor. Fusion protein technologies for biopharmaceuticals: applications and challenges. Hoboken: Wiley; 2013. p. 150-75.

140. Baldo BA. Chimeric fusion proteins used for therapy: indications, mechanisms, and safety. Drug Saf. 2015;38:455-79.

141. Purcell RT, Lockey RF. Immunologic responses to therapeutic biologic agents. J Investig Allergol Clin Immunol. 2008;18:335-42.
142. Enbrel ${ }^{\circledR}$ (etanercept) prescribing information. Immunex Corporation (Amgen). 2013. http://pi.amgen.com/united_states/enbrel/ derm/enbrel_pi.pdf. Accessed 7 Jun 2015.

143. Arcalyst ${ }^{\circledR}$ (rilonacept) prescribing information. Regeneron Pharmaceuticals. 2008. http://www.accessdata.fda.gov/drugsat fda_docs/label/2008/1252491bl.pdf. Accessed 7 Jun 2015.

144. Levin D, Golding B, Strome SE, et al. Fc fusion as a platform technology: potential for modulating immunogenicity. Trends Biotechnol. 2015;33:27-34.

145. Mitoma H, Horiouchi T, Tsukamoto H, et al. Mechanisms for cytotoxic effects of anti-tumor necrosis factor agents on transmembrane tumor necrosis factor $\alpha$-expressing cells: comparison among infliximab, etanercept, and adalimumab. Arthrit Rheumat. 2008;58:1248-57.

146. Davis PM, Abraham R, Xu L, et al. Abatacept binds to the Fc receptor CD64 but does not mediate complement-dependent cytotoxicity or antibody-dependent cellular cytotoxicity. J Rheumatol. 2007;34:2204-10.

147. Publishing La Merie. 2014 sales of recombinant therapeutic proteins and antibodies. Stuttgart: La Merie Publishing; 2015. 